\title{
Spectroscopic characterization, docking studies and reactive properties by DFT calculations of halogen substituted 6-Chloro-N-(3-iodo-4-methylphenyl)-pyrazine-2- carboxamide with MD simulations.
}

P. K. Ranjith ${ }^{\mathrm{a}, \mathrm{b}}$, Angel Ignatious ${ }^{\mathrm{c}}$, C. Yohannan Panicker ${ }^{\mathrm{d}}$, B. Sureshkumar ${ }^{\mathrm{e}}$, Stevan Armakovic ${ }^{\mathrm{f}}$, Sanja J. Armakovic ${ }^{\mathrm{g}}$, C. Van Alsenoy ${ }^{\mathrm{h}}$, P. L. Anto ${ }^{\mathrm{a}, \mathrm{c} *}$

a Department of Physics, Christ College (Autonomous), Irinjalakuda, Thrissur, University of Calicut, Kerala, India

${ }^{\mathrm{b}}$ Department of Physics, MPMMSN Trusts College, Shoranur, Palakkad, Kerala, India

c Department of Physics, St. Joseph's College (Autonomous), Irinjalakuda,

Thrissur, Kerala, India

d Thushara, Neethinagar-64, Kollam, Kerala, India

${ }^{\mathrm{e}}$ Department of Chemistry, S. N. College, Kollam, Kerala, India

${ }^{\mathrm{f}}$ University of Novi Sad, Faculty of Sciences, Department of Physics, Trg D.

Obradovica 4, 21000 Novi Sad, Serbia

${ }^{\mathrm{g}}$ University of Novi Sad, Faculty of Sciences, Department of Chemistry,

Biochemistry and Environmental Protection, Trg D. Obradovica 3, 21000 Novi

Sad, Serbia

${ }^{\mathrm{h}}$ Department of Chemistry, University of Antwerp, Groenenborgerlaan 171, B2020, Antwerp, Belgium

* Corresponding author: email address: antoponnore367@gmail.com (P. L. Anto)

\begin{abstract}
The spectral characterization of 6-Chloro-N-(3-iodo-4-methylphenyl)-pyrazine-2-carboxamide (CIMPPC) was executed by FT-IR and FT-Raman spectroscopic methods and density functional theory (DFT) computations have been carried using B3LYP/gen method. On the basis of potential energy distribution (PED) the vibrational assignments of the wavenumbers were proposed. NBO analysis was performed to study donor acceptor interactions. Halogen substitution results in increase in the $\mu$ (chemical potential) value in comparison with the parent molecule, which is a minimum. Halogen substitution also results a decrease in electrophilicity
\end{abstract}


index. Fundamental reactive properties of the title molecule is investigated by MEP analysis. Visualization of ALIE and Fukui functions evaluated the most probable sites for electrophilic attacks. Exposure of the title compound towards autoxidation and hydrolysis is evaluated using BDE and RDF. The compatible nature of the compound is investigated through the Hildebrand solubility parameter. CIMPPC exhibit inhibitory activity against the anti-inflammatory receptor transient receptor potential cation channel.

Keywords: Pyrazine, FT-IR, FT-Raman, DFT, ALIE, RDF, BDE, Solubility, Molecular docking.

\section{Introduction}

To inhibit protein kinases pyrazine products are used extensively, as representatives with antimycotic agent, antiseptic, antineoplastic and anticontagion activities [1]. Pyrazine moieties are found as medical and agricultural drug intermediates and also in a variety of vegetables like bell pepper, beets, asparagus and peanuts, in beef, blackberry, corn, grape fruit juice and breakfast cereal and is mainly used to blend the essence of cocoa, coffee, meat or potato flavor [2]. Pyrazinamide is a member of the pyrazine family and it is known as a very effective antimycobacterial agent, with a well-established role in tuberculosis treatment [3]. Pyrazine carboxamide used for the treatment of tuberculosis as it kills and stops the growth of certain pathogen that cause tuberculosis [4]. Pyrazinoic acid disrupts membrane energetics and inhibits membrane transport function in mycobacterium tuberculosis [5]. Silymarin, a standardized extract of milk thistle seeds also known as Silybium marianum which reduces the dysfunction of liver while maintains the glycemic control [6]. It is an effective antioxidant which prevents the further creation of free radicals by inactivating catalysts, removing the superoxide anion by converting to oxygen and hydrogen peroxide and hinders the lipid synthesis $[7,8]$. Ubiquitous use of pyrazine in perfume industry, baked food items and in pharmaceutical industry is responsible for the high interest in the compound $[9,10]$. The family of pyrazine compounds act as photosystem (PS) 2 inhibitors by hindering the photosynthetic electron transport chain in plants, which plays a vital role in ATP production [11-15]. In order to analyze the effect of halogen substitution, in the parent molecule, CIMPPC (26I), the position of iodine atom is replaced by bromine, chlorine and fluorine atoms respectively and which are designated as $26 \mathrm{Br}$, $26 \mathrm{Cl}, 26 \mathrm{~F}$. Similarly the positions of hydrogen atom in the parent molecule CIMPPC, $16 \mathrm{H}, 18 \mathrm{H}$ and $20 \mathrm{H}$ are replaced by iodine, bromine, chlorine and fluorine atoms respectively which are 
designated as 16I, 16Br, 16Cl, 16F, 18I, 18Br, 18Cl, 18F and 20I, 20Br, 20Cl, 20F. Spectroscopic calculations like FT-IR and FT- Raman were carried out in our compound and also to predict the hardness and stability of the compound we have calculated the Homo-Lumo energy gap. To evaluate the character and reactivity of the compound DFT calculations were carried out. To understand the stability of the title compound when exposed to water surroundings we evaluated the BDE (Bond dissociation energy) and RDF (Radial distribution functions) curves. Solubility parameter is very important in the case of pharmaceutical industry, we have also checked the compatibility of title compound towards the suitable excipient. Due to the vast biological activities of the compound Molecular docking was performed.

\section{Experimental Details}

The condensation of 6-chloropyrazine-2-carboxylic acid chloride with 3-iodo-4-methylaniline yielded 6-chloro- $N$-(3-iodo-4-methylphenyl)-pyrazine-2-carboxamide [15]. A mixture of 6chloropyrazine-2-carboxylic acid $(50.0 \mathrm{mmol})$ and thionyl chloride $(5.5 \mathrm{~mL}, 75.0 \mathrm{mmol})$ in dry toluene $(20 \mathrm{~mL})$ was refluxed for about $1 \mathrm{~h}$. Excess of thionyl chloride was removed by repeated evaporation with dry toluene in vacuo. The crude acyl chloride dissolved in dry acetone $(50 \mathrm{~mL})$ was added dropwise to a stirred solution of the 3-iodo-4-methylaniline $(50.0 \mathrm{mmol})$ in $50 \mathrm{~mL}$ of dry pyridine at room temperature. After the addition was complete, stirring continued for another $30 \mathrm{~min}$. The reaction mixture was then poured into $100 \mathrm{~mL}$ of cold water and the crude amide was collected and recrystallized from aqueous ethanol (scheme 1).

\subsection{6-Chloro-N-(3-iodo-4-methylphenyl)-pyrazine-2-carboxamide (CAS Registry Number: 1072927-31-1).}

Yield 83\%; Anal. Calcd. For $\mathrm{C}_{12} \mathrm{H}_{9} \mathrm{ClIN}_{3} \mathrm{O}$ (373.6): 38.58\% C, 2.43\% H, 11.25\% N; Found: $38.80 \% \mathrm{C}, 2.62 \% \mathrm{H}, 11.37 \%$ N. Mp 173.4-174.5 ${ }^{\circ} \mathrm{C}$; $\log P: 3.33 ; \operatorname{Clog} P: 3.54369 ; \mathrm{TLC}: R \mathrm{~F}=$ 0.81; 1H-NMR $\delta: 9.38(1 \mathrm{H}, \mathrm{s}, \mathrm{H} 3), 9.32(1 \mathrm{H}, \mathrm{bs}, \mathrm{NH}), 8.81(1 \mathrm{H}, \mathrm{s}, \mathrm{H} 5), 8.21(1 \mathrm{H}, \mathrm{d}, J=2.2 \mathrm{~Hz}$, H2'), 7.68 (1H, dd, J=8.2 Hz, J=2.2 Hz, H6'), and 7.24 (1H, d, J=8.2 Hz, H5'), 2.42 (3H, s, CH3); 13C-NMR $\delta: 159.2,147.6,147.4,143.7,142.2$, 138.3, 135.3, 129.9, 129.7, 119.8, 100.8, and 27.5. 


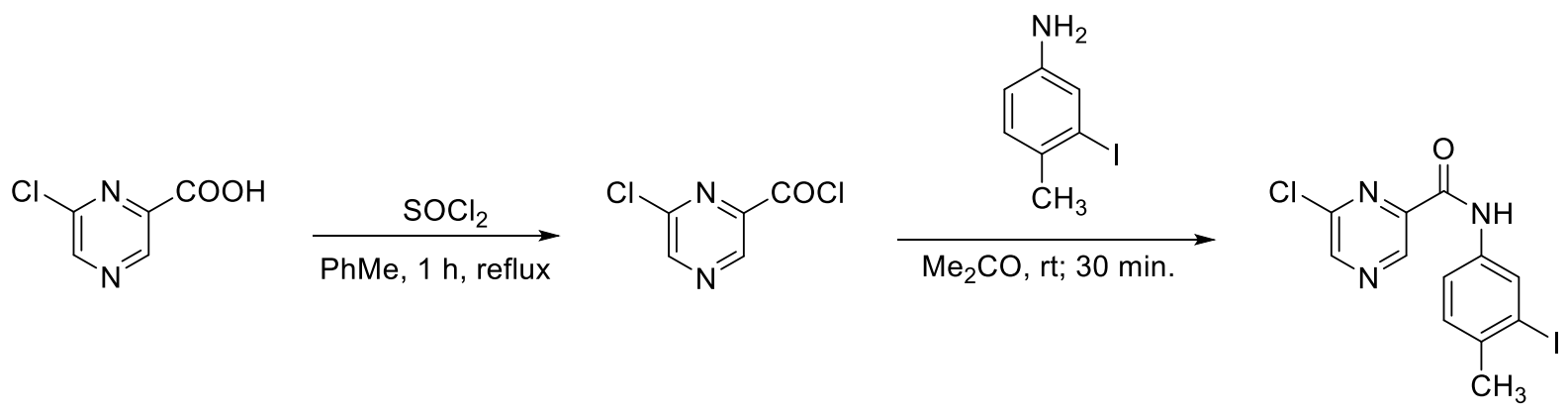

Scheme 1. Preparation of the target compound

Pyrazine derivatives have been synthesized and successfully evaluated as agents with diverse pharmacological effects, including but not limited to antiproliferative, antiinfective, and effects on cardiovascular or nervous system, and some of them have become clinically used drugs worldwide [16]. Pyrazinamide (PZA), a first-line anti-TB drug, was discovered through an effort to find antitubercular nicotinamide derivatives. Our research is focused on PZA analogues with a -CONH- bridge connecting the pyrazine and benzene rings. This moiety can form centrosymmetric dimer pairs with the peptidic carboxamido group of some peptides, needed for binding to the receptor site, possibly by formation of hydrogen bonds. 6-Chloro- $N$-(3-iodo-4methylphenyl)-pyrazine-2-carboxamide had minimal antimycobacterial activity (MIC = $8 \mathrm{mg} / \mathrm{L}$ ) against M. tuberculosis comparable with the standard PZA (MIC $=8 \mathrm{mg} / \mathrm{L})$ [17]. The photosynthesis inhibition, antialgal activity and the effect of a series of pyrazine derivatives as abiotic elicitors on the accumulation of flavonoids in a callus culture of Ononis arvensis (L.) were investigated and the most active inhibitor of the oxygen evolution rate in spinach chloroplasts was 6-Chloro- $N$-(3-iodo-4-methylphenyl)-pyrazine-2-carboxamide $\left(\mathrm{IC}_{50}=51.0 \mu \mathrm{mol} / \mathrm{L}\right)$. The maximal flavonoid production (about $900 \%$ ) was reached after a twelve-hour elicitation process with 6-Chloro- $N$-(3-iodo-4-methylphenyl)-pyrazine-2-carboxamide [15]. The FT-IR spectrum was recorded using $\mathrm{KBr}$ pellets on a DR/JASCO FT-IR 6300 spectrometer. The FT-Raman spectrum was obtained on a Bruker RFS 100/s, Germany. For excitation of the spectrum, the emission of Nd:YAG laser was used with an excitation wavelength of $1064 \mathrm{~nm}$, a maximal power $150 \mathrm{~mW}$; measurement of solid sample. 


\section{Computational Details}

Calculations of the title compound were carried with using the Gaussian09 program [18] using the B3LYP method, gen basis set for C, H, N, O atoms and LANL2DZ basis set for iodine atom to predict the molecular structure and wavenumbers in the gaseous phase and a scaling factor of 0.9613 had to be used for obtaining a considerably better agreement with the experimental data [19]. The assignments of the calculated wavenumbers are done using GAR2PED [20] and GaussView software [21]. DFT calculations were performed using Jaguar 9.0 program [22]. While MD simulations were carried out using Desmond program [23]. Using Jaguar program DFT calculations were carried out using B3LYP exchange-correlation functional, with 6$311++G(d, p), 6-31+G(d, p)$ and 6-311G(d,p) basis sets for the calculations of ALIE, Fukui functions, BDE and RDF respectIvely. In case of MD simulations the OPLS 2005 force field has been employed with simulation time set to $10 \mathrm{~ns}$ within isothermal- isobaric (NPT) ensemble class [24]. For MD simulations system was modeled by placing one CIMPPC molecule into the cubic box with $\sim 3000$ water molecules. Other parameters include temperature of $300 \mathrm{~K}$, pressure of 1.0325 bar and cut off radius of $12 \AA$. Schrödinger Materials Science Suite 2015-4 was used, Maestro GUI [25] was used for the preparation of input files and analysis of results.

\section{Results and Discussion}

In the following discussion, phenyl and pyrazine rings are designated as $\mathrm{Ph}$ and $\mathrm{Pz}$ respectively.

\subsection{Optimized geometrical parameters}

The C-N and C-C bond lengths in the pyrazine ring of the title compound are 1.3318, 1.3394, 1.3440, $1.3185 \AA$ and $1.3971,1.4038 \AA$, respectively, which are shorter than the normal C-N bond length (1.4900 ̊̊) and the C-C bond length (1.5400 ̊́). The reported C-N and C-C bond lengths of the pyrazine ring are 1.4104, 1.3577, 1.3577, $1.3608 \AA$ and 1.4121, $1.3517 \AA$ [26].

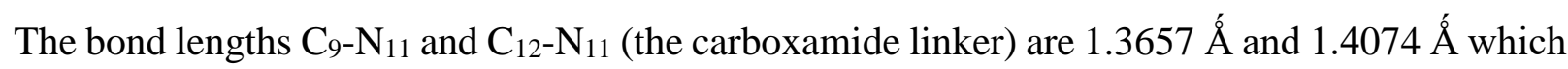
are also shorter than the normal C-N single bond and these bonds have some character of a double or conjugated bond [27]. The C-C bond lengths in the phenyl ring are in the range 1.38901.4043̊́. At $\mathrm{N}_{11}$ and $\mathrm{C}_{17}$ positions, the bond angles $\mathrm{C}_{9}-\mathrm{N}_{11}-\mathrm{H}_{21}, \mathrm{C}_{9}-\mathrm{N}_{11}-\mathrm{C}_{12}, \mathrm{C}_{12}-\mathrm{N}_{11}-\mathrm{H}_{21}$ and $\mathrm{C}_{14^{-}}$ $\mathrm{C}_{17-\mathrm{I}_{26},}, \mathrm{C}_{19}-\mathrm{C}_{17}-\mathrm{I}_{26}, \mathrm{C}_{14}-\mathrm{C}_{17}-\mathrm{C}_{19}$ are $114.3^{\circ}, 128.8^{\circ}, 116.9^{\circ}$ and $116.4,120.2$ and $123.4^{\circ}$ 
respectively. These asymmetries of angles are due to the weakening of the $\mathrm{N}-\mathrm{H}$ bond and iodine substitution in the phenyl ring respectively. The bond angles $\mathrm{C}_{4}-\mathrm{C}_{5}-\mathrm{N}_{6}, \mathrm{C}_{4}-\mathrm{C}_{5}-\mathrm{C}_{9}, \mathrm{C}_{9}-\mathrm{C}_{5}-\mathrm{N}_{6}$ at $\mathrm{C}_{5}$ are $121.2,120.0$ and $118.8^{\circ}$ respectively. This asymmetry is attributed to the interaction of pyrazine ring and carboxamide group. The bond angles $\mathrm{C}_{17}-\mathrm{C}_{19}-\mathrm{C}_{22}, \mathrm{C}_{15}-\mathrm{C}_{19}-\mathrm{C}_{22}, \mathrm{C}_{17}-\mathrm{C}_{19}-\mathrm{C}_{15}$ at $\mathrm{C}_{19}$ are $123.9,120.2,115.9^{\circ}$ and the asymmetry is due to the interaction of the neighboring groups.

\subsection{IR and Raman Spectra}

The calculated wavenumbers, observed Raman, IR bands and the assignments are given in Table 2. According to literature, the $\mathrm{NH}$ vibrations are expected in the region, $3390 \pm 60 \mathrm{~cm}^{-1}$ (stretching), in the range 1500-1200 and in the region $790 \pm 70 \mathrm{~cm}^{-1}$ (bending modes) [28-31]. For the title compound, these modes were assigned at $3330 \mathrm{~cm}^{-1}$ (IR), $3494 \mathrm{~cm}^{-1}$ (Raman), 3418 $\mathrm{cm}^{-1}$ (DFT) (stretching), $1509 \mathrm{~cm}^{-1}$ (DFT) (in-plane bending), 674 (IR), 668 (Raman), $667 \mathrm{~cm}^{-1}$ (DFT) (out-of-plane bending). For the title compound, the NH stretching mode has an IR intensity of 76.90 and Raman activity of 247.15 with a PED of $91 \%$. The PED of NH deformation modes of the title compound are in between 34 and 44\%. For the deformation mode at $667 \mathrm{~cm}^{-1}$, the IR intensity is low while the other mode has high IR intensity for the title compound. In the present case, the NH stretching mode is red shifted by $88 \mathrm{~cm}^{-1}$ in the IR spectrum from the computed value, which indicates the weakening of the $\mathrm{NH}$ bond [32]. The $\mathrm{CN}$ stretching modes are expected in the region $1275 \pm 55 \mathrm{~cm}^{-1}$ [28] and the bands at $1232 \mathrm{~cm}^{-1}$ (DFT) with low IR intensity and PED around $28 \%$, at $1230 \mathrm{~cm}^{-1}$ (IR) spectrum and $1237 \mathrm{~cm}^{-1}$ (Raman) spectrum are assigned as the $\mathrm{CN}$ stretching modes of the title compound. The reported $\mathrm{CN}$ stretching modes are at $1265,1239 \mathrm{~cm}^{-1}$ in the IR spectrum and at $1261,1248 \mathrm{~cm}^{-1}$ (DFT) [33]. For the title compound, the carbonyl stretching vibration is observed at $1670 \mathrm{~cm}^{-1}$ in the IR spectrum and at $1667 \mathrm{~cm}^{-1}$ in the Raman spectrum which is expected in the region $1715-1600 \mathrm{~cm}^{-1}$ [28], while the computed value is $1706 \mathrm{~cm}^{-1}$ with an IR intensity of 198.96 and Raman activity 153.36 and the PED is $66 \%$. According to literature [28], the $\mathrm{CH}_{3}$ modes are expected in the regions 3050$2900 \mathrm{~cm}^{-1}$ (stretching), 1485-1350, 1100-900 $\mathrm{cm}^{-1}$ (deformation modes) and for the title compound, these modes are assigned at 3024, 2982, $2925 \mathrm{~cm}^{-1}$ (IR), 2957, $2924 \mathrm{~cm}^{-1}$ (Raman), 3010, 2987, $2934 \mathrm{~cm}^{-1}$ (DFT) (stretching), 1433, $1031 \mathrm{~cm}^{-1}$ (IR), $1035 \mathrm{~cm}^{-1}$ (Raman) and in between 1462-989 $\mathrm{cm}^{-1}$ (DFT) (bending). Analysis of vibrational spectra of substituted benzenes shows that the stretching vibrations of CI corresponds to a band around $340 \mathrm{~cm}^{-1}$ experimentally $[34,35]$. The carbon-iodine stretching band of the title compound is assigned at $311 \mathrm{~cm}^{-1}$ 
theoretically, $271 \mathrm{~cm}^{-1}$ experimentally. Zainuri et al. reported the CI stretching mode at $317 \mathrm{~cm}^{-}$ ${ }^{1}$ [36]. For the title compound, the phenyl $\mathrm{CH}$ stretching bands are observed at $3062 \mathrm{~cm}^{-1}$ in the IR spectrum and $3063 \mathrm{~cm}^{-1}$ in the Raman spectrum, while the computed values are in the range $3159-3059 \mathrm{~cm}^{-1}$ which are in agreement with the literature $[28,37]$. The phenyl ring stretching modes of the title compound are observed at $1580,1485,1298 \mathrm{~cm}^{-1}$ in the IR spectrum, at 1598 , $1561,1302 \mathrm{~cm}^{-1}$ in the Raman spectrum and at 1596, 1571,1476, 1373, $1291 \mathrm{~cm}^{-1}$ theoretically (DFT) [29]. The tri-substituted phenyl ring breathing mode of the title compound is assigned at $862 \mathrm{~cm}^{-1}$ (IR), $866 \mathrm{~cm}^{-1}$ (Raman) and $858 \mathrm{~cm}^{-1}$ (DFT) with PED 21\% which is in agreement with the literature [38]. The in-plane and out-of-plane $\mathrm{CH}$ deformations of the phenyl ring are expected above and below $1000 \mathrm{~cm}^{-1}$ respectively [28] and these modes of the title compound were assigned at 1269, 1248, $1193 \mathrm{~cm}^{-1}$ (DFT), 1166, $926 \mathrm{~cm}^{-1}$ (IR), 1179 (Raman) (in-plane bending modes), 908, 890, $794 \mathrm{~cm}^{-1}$ (DFT) (out-of-plane bending modes). The IR bands in the region of 2676-1800 $\mathrm{cm}^{-1}$ and the large broadening seen in the IR spectrum support the intramolecular hydrogen bonding [39]. The pyrazine $\mathrm{CH}$ stretching modes of the title compound were observed at $3116,3093 \mathrm{~cm}^{-1}$ theoretically which are expected in the range $3100-3000 \mathrm{~cm}^{-1}$ [40]. In the present case, the pyrazine ring stretching modes were observed at $1520,1121 \mathrm{~cm}^{-1}$ in the IR spectrum and at $1525,1395,1118 \mathrm{~cm}^{-1}$ in the Raman spectrum while the PED analysis gives these modes in a range $1548-1145 \mathrm{~cm}^{-1}$ which are in agreement with literature $[2,33]$. In the present case, the pyrazine ring stretching modes have IR intensities in the range 2.18 to 59.64 and Raman activities 6.05 to 477.37 and the PEDs are around 50\%. For the title compound, the ring breathing mode of the pyrazine ring was assigned at $991 \mathrm{~cm}^{-1}$ in the DFT with low IR intensity and Raman activity, while the reported value is at $1015 \mathrm{~cm}^{-1}$ (DFT) [2]. For the title compound, the in-plane and out-of-plane $\mathrm{CH}$ bending modes of the pyrazine ring were assigned at 1384, 1158, 943 and $884 \mathrm{~cm}^{-1}$ theoretically. The experimentally observed values are 1147, 958 $\mathrm{cm}^{-1}$ which are in agreement with the literature [2].

\subsection{Natural Bond Orbital Analysis}

The NBO (Natural Bond Orbital) calculations were performed using NBO 3.1 program [41]. The important interactions are: $\mathrm{LPCl}_{27} \rightarrow \mathrm{C}_{1}-\mathrm{N}_{6}, \mathrm{LPN}_{11} \rightarrow \mathrm{C}_{12}-\mathrm{C}_{13}, \mathrm{LPN}_{11} \rightarrow \mathrm{C}_{9}-\mathrm{O}_{10}, \mathrm{LPO}_{10} \rightarrow \mathrm{C}_{9}-\mathrm{N}_{11}$, $\mathrm{LPO}_{10} \rightarrow \mathrm{C}_{5}-\mathrm{C}_{9}, \mathrm{C}_{15}-\mathrm{C}_{19} \rightarrow \mathrm{C}_{14}-\mathrm{C}_{17}$ and $\mathrm{C}_{15}-\mathrm{C}_{19} \rightarrow \mathrm{C}_{12}-\mathrm{C}_{13}$ with energies, 14.26, 31.00, 50.74, 22.46, 18.84, 23.23 and $22.77 \mathrm{kcal} / \mathrm{mol}$. $100 \%$ p-character is found in $\mathrm{Cl}_{27}, \mathrm{I}_{26}, \mathrm{~N}_{11}$ and $\mathrm{O}_{10}$. The NBO interactions are tabulated in Tables 3 and 4. 


\subsection{Nonlinear optical properties}

The calculated first hyperpolarizability of the title compound is $24.973 \times 10^{-30}$ esu which is 192.1 times that of standard NLO material urea $\left(0.13 \times 10^{-30} \mathrm{esu}\right)$ [42]. For a pyrazine derivative the first hyperpolarizability is reported at $9.77 \times 10^{-30}$ esu [26]. We conclude that the title compound is an attractive object for future studies of nonlinear optical properties. In CIMPPC halogen substitution increases the dipole moment in the order $26>18>16>20$. Highest dipole moment value is noticed for $26 \mathrm{Cl}$ and lowest value for 20I. Highest polarizability $(\alpha)$ value is noticed for 20I and lowest value for 18I. For first order hyperpolarizability, $\beta$ value decreased to a large extent for $18^{\text {th }}$ position for $\mathrm{F}, \mathrm{Cl}$ and I except $\mathrm{Br}$. Highest $\beta$ value is noticed for $20 \mathrm{I}$ and lowest value for $18 \mathrm{Cl}$.

\subsection{Frontier Molecular Orbitals}

In order to understand global stability and reactive properties of the title compound we have investigated frontier molecular orbitals. Namely, the highest occupied molecular orbital (HOMO) and lowest unoccupied molecular orbital (LUMO) are the main molecular orbitals that take part in reactions with other molecular structures. Distribution of HOMO and LUMO provides important insight into the reactive properties of organic molecules. The HOMO-LUMO visualization is represented in Fig. 4. Frontier molecular orbital study is used to explain the chemical behaviour and stability of the molecular system. The delocalization of HOMO and LUMO over the molecular system shows the charge transfer within the molecular system. The HOMO-LUMO gap for the title compound is found to be $0.834 \mathrm{eV}$. The chemical descriptors can be evaluated by using HOMO and LUMO orbital energies, $\mathrm{E}_{\text {HOMO }}$ and $\mathrm{E}_{\mathrm{LUMO}}$ as: ionization energy $\mathrm{I}=-\mathrm{E}_{\mathrm{HO} \mathrm{O}}$, electron affinity $\mathrm{A}=-\mathrm{E}_{\mathrm{LUMO}}$, hardness $\eta=(\mathrm{I}-\mathrm{A}) / 2$, chemical potential $\mu=-$ $(\mathrm{I}+\mathrm{A}) / 2$ and electrophilicity index $\omega=\mu 2 / 2 \eta[43]$. For the title compound, $\mathrm{I}=5.934, \mathrm{~A}=5.100$, $\eta=0.417, \mu=-5.517$ and $\omega=36.496 \mathrm{eV}$. For the title compound the HOMO is delocalized over the entire iodine atom and slightly over the phenyl ring and $\mathrm{CH}_{3}$ group while the LUMO is delocalized over the entire molecule except iodine, chlorine atom and $\mathrm{CH}_{3}$ group. For halogen substitution $26 \mathrm{Br}$, HOMO is delocalized only over the pyrazine ring. For $26 \mathrm{Cl}$ substitution HOMO is delocalized over the entire molecule except the $\mathrm{C}=\mathrm{O}$ group and the nitrogen atom (position 3) of pyrazine ring. For $26 \mathrm{~F} \mathrm{HOMO}$ is over entire pyrazine ring except nitrogen (position 3). While for $26 \mathrm{Br}, 26 \mathrm{Cl}$ and $26 \mathrm{~F}$ the $\mathrm{LUMO}$ delocalization is same over the entire molecule except the $\mathrm{CH}_{3}$ group, chlorine atom and corresponding halogen atoms. For halogen 
substitution 16I HOMO is delocalized the entire phenyl ring and iodine atom. For $16 \mathrm{Br}$ the $\mathrm{HOMO}$ is over entire pyrazine ring except nitrogen atom (position 3). For 16Cl HOMO is delocalized entire phenyl ring, $\mathrm{C}=\mathrm{O}$ group and slightly over the pyrazine ring. For $16 \mathrm{~F}$ the HOMO is delocalized over entire pyrazine ring except nitrogen atom (positon 3) and slightly over the phenyl ring and nitrogen atom of carboxamide group. For halogen substitution 16I, 16Br, $16 \mathrm{Cl}$ and $16 \mathrm{~F}$ the LUMO delocalization is the same over the entire molecule except the $\mathrm{CH}_{3}$ group, chlorine atom and the corresponding halogen atoms and this is also as in the previous halogen substitutions. For halogen substitutions 18I the HOMO is strongly delocalized over the iodine atom. For halogen substitution $18 \mathrm{Br}$ the $\mathrm{HOMO}$ is over entire pyrazine ring except nitrogen atom (Position 3). For $18 \mathrm{Cl}$ substitution the $\mathrm{HOMO}$ is delocalized strongly over the entire phenyl ring and slightly over the pyrazine ring and carboxamide group. For halogen substitution $18 \mathrm{~F}$ the HOMO is delocalized over entire pyrazine ring. For halogen substitutions $18 \mathrm{I}$ and $18 \mathrm{~F}$ the LUMO is localized same over entire pyrazine ring and carboxamide group. Similarly for halogen substitutions $18 \mathrm{Br}$ and $18 \mathrm{Cl}$ the $\mathrm{LUMO}$ delocalization is strong over entire pyrazine ring except chlorine atoms. For halogen substitution 20I the HOMO is delocalized strongly around the iodine atom. For the halogen substitutions $20 \mathrm{Br}$ and $20 \mathrm{~F}$ the HOMO is delocalized strongly over the entire pyrazine ring except the nitrogen atom (Position 3). For halogen substitution $20 \mathrm{Cl}$ the $\mathrm{HOMO}$ is strongly delocalized over entire pyrazine ring except nitrogen atom (position 3) and also substituted chlorine atom and partially over phenyl ring. For $20 \mathrm{I}$ and $20 \mathrm{Cl}$ the LUMO is delocalized strongly over the pyrazine ring except chlorine atom and slightly over carboxamide and phenyl group. For halogen substitution $20 \mathrm{Br}$ the LUMO is over entire molecule except $\mathrm{CH}_{3}$ group, bromine and chlorine atoms. For halogen substitution 20F, LUMO is delocalized over the entire pyrazine ring except chlorine atom, slightly over carboxamide group and phenyl ring. The average value of chemical potential decreases for the halogen substitution in the order 26I, 16I, 18I, 20I less than $26 \mathrm{Cl}, 16 \mathrm{Cl}, 18 \mathrm{Cl}, 20 \mathrm{Cl}$ less than $26 \mathrm{~F}$, $16 \mathrm{~F}, 18 \mathrm{~F}, 20 \mathrm{~F}$ less than $26 \mathrm{Br}, 16 \mathrm{Br}, 18 \mathrm{Br}, 20 \mathrm{Br}$. Chemical potential value of $16 \mathrm{Br}$ is deviated maximum from the parent molecule while all other halogen substitution shows considerable deviation. Halogen substitution results in increase in the $\mu$ value in comparison with the parent molecule, which is a minimum. Halogen substitution also results a decrease in electrophilicity index and is minimum for $18 \mathrm{Br}$. Global hardness is higher for $18 \mathrm{Br}$ because of its large HOMOLUMO gap which results a decrease in polarizability 


\subsection{Molecular Electrostatic Potential Map}

Molecular electrostatic potential and electron density are related to each other to find the reactive sites for electrophilic and nucleophilic sites $[44,45]$. The negative (red and yellow) regions of MEP map were related to electrophilic reactivity while the positive (blue) regions to nucleophilic reactivity. For the parent molecule, most electrophilic (red and yellow) regions are around $\mathrm{C}=\mathrm{O}$ of carboxamide group, deeply over entire phenyl ring, and slightly near nitrogen atom (position 3 ) and the nucleophilic regions (blue) are deeply over iodine atom and slightly over the pyrazine ring (Fig. 5). For halogen substitutions $26 \mathrm{Br}, 26 \mathrm{Cl}, 26 \mathrm{~F}$, the electrophilic regions are strongly over the $\mathrm{C}=\mathrm{O}$ group of carboxamide, slightly over the phenyl ring and nitrogen atom (position 3) while the nucleophilic regions are over the N-H of carboxamide group and the pyrazine ring but the blue region deeply over pyrazine ring in $26 \mathrm{Br}$ is more pronounced. For iodine substitution in $16 \mathrm{I}$ the electrophilic regions are around $\mathrm{C}=\mathrm{O}$ of carboxamide group, deeply over phenyl ring and slightly near N-H bond and the blue region is deeply over iodine atom and pyrazine ring. For halogen substitution $16 \mathrm{Br}$, the electrophilic regions are at $\mathrm{C}=\mathrm{O}$ region, slightly over phenyl ring and deeply over N-H bond. For chlorine and fluorine substitution $16 \mathrm{Cl}, 16 \mathrm{~F}$ the electrophilic regions are similar to that of bromine substitution while the nucleophilic regions are similar to that of bromine substitution but blue region of chlorine atom in $16 \mathrm{Cl}$ is more pronounced. For halogen substitutions $18 \mathrm{Br}, 18 \mathrm{Cl}, 18 \mathrm{~F}$ the electrophilic behavior is around $\mathrm{C}=\mathrm{O}$ and slightly over phenyl ring is identical to that of $18 \mathrm{I}$ where red region is slightly over nitrogen atom (position 3) while the nucleophilic region is identical to that of $18 \mathrm{I}$. For the halogen substitutions $20 \mathrm{Br}, 20 \mathrm{Cl}$ and $20 \mathrm{~F}$ the red region is over $\mathrm{C}=\mathrm{O}$, slightly over phenyl ring and near nitrogen atom (position 3) while the blue region is near $\mathrm{N}-\mathrm{H}$ bond and over pyrazine ring. For halogen substitution $20 \mathrm{I}$ the electrophilic region is deeply over $\mathrm{C}=\mathrm{O}$, entire phenyl ring and near nitrogen atom (position 3) while the nucleophilic region is deeply over iodine atom and around pyrazine ring.

\subsection{ALIE surfaces and Fukui functions}

ALIE (Average local ionization energy) is a quantum molecular descriptor which indicates the local reactivity and also the energy required to remove an electron from the molecule. So we can say that the sites with least values of ALIE are the most probable sites for an electrophilic attack $[46,47]$. According to the equation given below ALIE is the sum of orbital energies weighted by the orbital density. 


$$
I(r)=\sum_{i} \frac{\rho_{i}(\vec{r})\left|\varepsilon_{i}\right|}{\rho(\vec{r})}
$$

Where $\rho_{i}(\vec{r})$ denotes electronic density of the i-th molecular orbital at the point $\vec{r}, \varepsilon_{i}$ denotes

orbital energy and $\rho(\vec{r})$ denotes total electronic density function. We have mapped the ALIE values to the electron density surface in order to foresee the attacking sites of electrophiles. The ALIE figure is represented in Fig. 6. Here in this figure we can see that the Iodine atom and benzene ring shows the least ALIE values that is $179.47 \mathrm{kcal} / \mathrm{mol}$. On the other side in the close vicinity of hydrogen atoms $\mathrm{H}_{24}, \mathrm{H}_{21}, \mathrm{H}_{8}, \mathrm{H}_{7}$ the highest ALIE value $332.15 \mathrm{kcal} / \mathrm{mol}$ is visible. The functional derivative of chemical potential with respect to external potential is termed as Fukui functions. It is also used to predict the reactivity sites. When we go through the maxwell's relations we can interpret this as the derivative of electronic density with respect to the number of electrons $[48,49]$. In physical sense it is the change in electron density as a consequence of change in charge. These functions in Jaguar program are calculated with the help of finite difference approach, according to the following equations:

$$
\begin{aligned}
& f^{+}=\frac{\left(\rho^{N+\delta}(r)-\rho^{N}(r)\right)}{\delta}, \\
& f^{-}=\frac{\left(\rho^{N-\delta}(r)-\rho^{N}(r)\right)}{\delta},
\end{aligned}
$$

where $N$ stands for the number of electrons in reference state of the molecule, while $\delta$ stands for the fraction of electron which default value is set to be 0.01 [50]. By plotting fukui functions to electron density surfaces we get a convenient information about the important molecular sites acting as a reactive center [46,47]. The Fukui function plot is represented in Fig. 7. The colour coding in the plot is as follows, purple (positive) colour in Fukui function $f^{+}$means the electron density has been increased by the addition of charges to the system while red (negative) colour in Fukui function $f^{-}$means the electron density has been diminished by the addition of charges. Electron density is increased in the near vicinity of carbon atoms $\mathrm{C}_{12}, \mathrm{C}_{22}, \mathrm{C}_{17}$ and electron density is decreased near the $\mathrm{Cl}_{27}$ atom.

\subsection{Reactive and degradation properties based on autoxidation and hydrolysis}

BDEs and RDFs are calculated to predict degradation properties based on autoxidation and hydrolysis mechanisms. Calculations of BDE for hydrogen abstraction allow the possibility to 
predict molecular sites where autoxidation process could start. It gives information about upto what extent some molecule are sensitive to presence of oxygen and open air, a parameter that is of very much importance in pharmaceutical industry. BDE also helps us to understand the forced degradation studies, since they can be used for confirmation and determination of degradation path of some organic pharmaceutical molecule [51-54]. Wright et al. says that the target molecule is most vulnerable to autoxidation if the BDE for hydrogen abstraction ranges from 70 to 85 $\mathrm{kcal} / \mathrm{mol}$ [55]. BDE values for hydrogen abstraction lower than $70 \mathrm{kcal} / \mathrm{mol}$, are not suitable for the autoxidation mechanism since formed radicals are resistant for $\mathrm{O}_{2}$ insertion [55-57]. Fig.8 contains all BDE values for CIMPPC. Red colored values represent the BDE values for hydrogen abstraction and blue colored values correspond to the BDE values for the rest of the single acyclic bonds. All the BDE values of molecule are greater than $90 \mathrm{kcal} / \mathrm{mol}$ so we can say that the molecule is stable in the presence of oxygen and open air. To find the extend of hydrolysis we have also calculated the RDF for the molecule. In fig.9 RDFs of atoms with the most pronounced interactions with water molecules are presented. In RDF plot, $\mathrm{g}(r)$ represents the probability of finding a particle in the distance $r$ from another particle [58]. Results provided in Fig.9 indicate that only four atoms of CIMPPC molecule have relatively significant interactions with water molecules. These atoms are $\mathrm{C}_{22}, \mathrm{O}_{10}, \mathrm{I}_{26}$ and $\mathrm{Cl}_{27}$ which shows similar g(r) profile. Peak distance in all cases is located between 2.9 to $3.9 \AA$. According to the maximal $\mathrm{g}(\mathrm{r})$ values the most important RDF is certainly for chlorine atom. Here the high peak and absence of hydrogen atoms indicates the possibility of the stability of molecule in water surroundings which is a very important property in the pharmaceutical industry

\subsection{Solubility parameter}

The production of new pharmaceutical care products and the identification of the active ingredient are emerging fields. There are certain parameters to be satisfied by the molecules for considering the drug production. Some of them are stability, solubility and deliverability of the active ingredient. The molecules which lack these physical properties must be modified. By mixing them with the excipient we can modify the active ingredient without any structural changes. A wide range of excipients are identified over the past decade. Excipients can be identified using experimental as well as computational methods. Experimental identification is a very time consuming process, while computational methods can be used to neutralize the 
possibilities. Compatibility is one of the major property needed between the active ingredient and the excipient. Hildebrand solubility parameter can be used to predict the compatible nature of both [59-61]. The solubility parameter of active component and that of the excipient must be same. The equation for the solubility parameter using MD calculations is given below

$$
\delta=\sqrt{\frac{\Delta H_{V}-R T}{V_{m}}}
$$

In this work, the solubility parameter has been calculated for the CIMPPC molecule. The value is compared with three compounds polyvinylpyrrolidone polymer (PVP), maltose, and sorbitol. MD systems used to calculate this quantity consisted of 32 molecules placed in a cubic simulation box. Solubility parameters of all mentioned compounds have been summarized in Table 7. As indicated by the results presented in Table 7, CIMPPC molecule has the highest compatibility with the Maltose compound. In this particular case, the difference between corresponding values of solubility parameter is less than $5.5 \mathrm{MPa}^{1 / 2}$, indicating very high compatibility. Solubility parameter of sorbitol is much higher than the solubility parameter of the CIMPPC molecule. Therefore, the MD calculations suggest that it is reasonable to consider Maltose as an excipient for CIMPPC molecule.

\subsection{Molecular docking}

Molecular docking was employed to recognize the active site of the receptor, and acquire the best geometry of ligand-receptor complex. Based on the structure of a compound, PASS (Prediction of Activity Spectra) [62] is an online tool which predicts different types of activities. We choose the activity Vanilloid 1 agonist with $\mathrm{Pa}$ value 0.708 and high resolution crystal structure of corresponding protein transient receptor potential cation channel (PDB ID: 4DX1) was downloaded from the RCSB protein data bank website. Transient receptor potential vanilloid 1 (TRPV1), a non-selective cation channel. TRPV1 is thought to be a central transducer of hyperalgesia and a prime target for controlling pain pharmacologically because it is a point where many proalgesic pathways converge and it is upregulated and sensitized by inflammation and injury [63]. A novel transient receptor potential vanilloid 1 (TRPV1) agonist inhibits TNF-alpha production through the activation of capsaicin-sensitive afferent neurons and treatment of chronic inflammation [64]. Pharmacologically active pyrazine N-acylhydrazone (NAH) derivatives, is used as novel analgestic and anti-inflammatory drug candidates [65]. Thus we choose title compound as ligand and transient receptor potential cation channel as target for docking study. 
All molecular docking calculations were performed on AutoDock4.2 [66] and Auto Dock-Vina software [67]. The original ligands as well as water molecules were removed from the crystal structure and polar hydrogens and united atom Kollman charges were assigned for the receptor using the graphical user interface Auto Dock Tools (ADT). The Lammarckian Genetic Algorithm (LGA) [68] was employed to calculate the energy between ligand and receptor. The compound docked the active site of receptors with the grid centre dimension $40 \times 40 \times 40$. The conformations with the lowest binding energy is extracted and analyzed for detailed interactions in Discovery Studio Visualizer 4.0 software. The ligand binds at the active site of the substrates by weak noncovalent interactions (Fig.10 and Fig. 11). The amino acid Arg186 forms two H-bond with carbonyl group while Thr190 has a H-bond with NH group. Pro230 having a H-bond with pyrazine ring. The docked ligand forms a stable complex with transient receptor potential cation channel and the binding free energy value is $-5.9 \mathrm{kcal} / \mathrm{mol}$ (Table 9). These preliminary results suggest that the compound having inhibitory activity against the anti-inflammatory receptor transient receptor potential cation channel. Thus the title compound can be developed as drug used for the treatment of pain and inflammation.

\section{Conclusion}

FT-IR and FT Raman spectra of 6-chloro-N-(3-iodo-4 methyl phenyl) pyrazine-2carboxamide were recorded and analyzed. The vibrational wavenumbers were computed at B3LYP theory. The data obtained from theoretical calculation are used to assign vibrational band obtained experimentally. The geometrical parameters of the title compound are in agreement with similar derivatives. For the title compound the HOMO is delocalized over the entire iodine atom and LUMO is delocalized over the entire except iodine atom also halogen substituted HOMO-LUMO calculations are conducted the lowering of HOMO-LUMO band gap support the bioactive property of the molecule. The molecular electrostatic potential study showed that for the parent molecule most electrophilic regions are around $\mathrm{C}=\mathrm{O}$ of carboxamide group and the nucleophilic region deeply over iodine atom. The NBO analysis performed in this study enabled us to know about the conjugate interactions taking place within the molecular spices. The calculated first hyperpolarizability of the title compound is 192.1 times that of standard NLO material, which is suitable for non-linear optical activity. By DFT calculations we were able to calculate the ALIE values, beside benzene ring and iodine atom we have determined $\mathrm{H}_{24}, \mathrm{H}_{21}, \mathrm{H}_{8}, \mathrm{H}_{7}$ are prone to electrophilic attacks. The 
mapping of Fukui functions against electron density shows that carbon atoms $\mathrm{C}_{12}, \mathrm{C}_{22}$, $\mathrm{C}_{17}$ and chlorine atom $\mathrm{Cl}_{27}$ are important reactive centers. Calculation of $\mathrm{BDE}$ and $\mathrm{RDF}$ showed that title molecule is not sensitive in the water surroundings towards auto oxidation and degradation mechanisms. The MD calculations of solubility parameter suggests that it is reasonable to consider Maltose as an excipient for CIMPPC molecule. By molecular docking the compound forms a stable complex with Transient receptor potential vanilloid 1 (TRPV1).

\section{Acknowledgments}

The authors would like to extend their sincere gratitude to the Department of physics, University of Novi Sad for the MD calculations. Part of this work has been performed, thanks to the support received from Schrodinger Inc.

\section{References}

[1] D. R. Boubee, C. V. Leeuwen, D. Dubourdieu, Organoleptic impact of 2-methoxy-3isobutylpyrazine on red brodeaux and loire wines, effect of environmental conditions on concentrations in grapes during ripening, J. Agric. Food Chem. 48 (2000) 4830-4834.

[2] H. Endredi, F. Billes, S. Holly, Vibrational spectroscopic and quantum chemical study of chlorine substitution of pyrazine, J. Mol. Struct. Theochem. 633 (2003) 73-82.

[3] A. Somoskovi, M. M. Wade, Z. Sun, Y. Zhang, Iron enhances the antituberculous activity of pyrazinamide, J. Antimicrob. Chemother. 53 (2004) 192-196.

[4] V. Opletalova, Jirı. Hartl, A. Patel, K. Palat Jr., V. Buchta, Ring substituted 3-phenyl-1(2-pyrazinyl)-2-propen-1-ones as potential photosynthesis-inhibiting, antifungal and antimycobacterial agents, Il Farmaco 57 (2002) 135-144.

[5] Y. Zhang, M. M. Wade, A. Scorpio, H. Zhang Z. Sun, Mode of action of pyrazinamide: disruption of Mycobacterium tuberculosis membrane transport and energetics by pyrazinoic acid J. of Antimicrob. Chemother. 52 (2003) 790-795.

[6] V. Křen, D. Walterova, Silybin and silymarin-New effects and applications. Biomed. Pap. 149 (2005) 29-41.

[7] S. S. Raza, M. M. Khan, M. Ashafaq, A. Ahmad, G. Khuwaja, A. Khan, Silymarin protects neurons from oxidative stress associated damages in focal cerebral ischemia: A 
behavioral, biochemical and immune histological study in Wistar rats. J. Neurol. Sci. 309 (2011) 45-54.

[8]. N. K. Singhal, G. Srivastava, D. K. Patel, S. K. Jain, M. P. Singh, Melatonin or silymarin reduces maneb- and paraquat-induced Parkinson's disease phenotype in the mouse. J. Pineal Res. 50 (2011) 97-109.

[9] W. J. Chung, A. Kornilov, B. H Brodsky, M. Higgins, T. Sanchez, L. B. Heifets, M. H. Cynamon, J. Welch, Inhibition of M. tuberculosis in vitro in monocytes and in mice by aminomethylene pyrazinamide analogs. Tuberculosis 88 (2008) 410-419.

[10] B. Servusová, D. Eibinová, M. Doležal, V. Kubícek, P. Paterová, M. Peško, Substituted N-benzylpyrazine-2-carboxamides: Synthesis and biological evaluation, Molecules 17 (2012) 13183-13198.

[11] D. M. Král'ová, K. Herbicides, Theory and Applications: Synthesis and Evaluation of Pyrazine Derivatives with Herbicidal Activity. In Tech; 2011.

[12] M. Doležal, K. Král'ová, Synthesis and Evaluation of Pyrazine Derivatives with Herbicidal Activity. In Herbicides, Theory and Applications; S Soloneski, M.L. Larramendy, Eds.; In Tech: Vienna, Austria, (2011) 581-610.

[13] M. Dolezal, J. Zitko, Z. Osicka, J. Kunes, M. Vejsova, V. Buchta, J. Dohnal, J. Jampilek, K. Kralova, Synthesis, antimycobacterial, antifungal and photosynthesis-inhibiting activity of chlorinated N-phenylpyrazine-2-carboxamides. Molecules 15 (2010) 85678581 .

[14] M. Dolezal, P. Cmedlova, L. Palek, J. Vinsova, J. Kunes, V. Buchta, J. Jampilek, K Kralova, Synthesis and antimycobacterial evaluation of substituted pyrazine carboxamides. Eur. J. Med. Chem. 43 (2008) 1105-1113.

[15] M. Doležal, L. Tumová, D. Kešetovičová, J. Tuma, K. Králová, Substituted Nphenylpyrazine-2-carboxamides, their synthesis and evaluation as herbicides and abiotic elicitors. Molecules 12 (2007) 2589-2598.

[16] M. Dolezal, J. Zitko, Pyrazines Derivatives: a patent review (June 2012-present). Exp. Opin. Ther. Pat., 25 (2015) 33-47.

[17] M. Dolezal, J. Zitko, D. Kesetovicova, J. Kunes, M. Svobodova, Substituted NPhenylpyrazine-2-carboxamides: Synthesis and Antimycobacterial Evaluation. Molecules 14 (2009) 4180-4189.

[18] Gaussian 09, Revision B.01, M. J. Frisch, G. W. Trucks, H. B. Schlegel, G. E. Scuseria, M. A. Robb, J. R. Cheeseman, G. Scalmani, V. Barone, B. Mennucci, G. A. Petersson, H. Nakatsuji, M. Caricato, X. Li, H. P. Hratchian, A. F. Izmaylov, J. Bloino, G. Zheng, 
J. L. Sonneberg, M. Hada, M. Ehara, K. Toyota, R. Fukuda, J. Hasegawa, M. Ishida, T. Nakajima, Y. Honda, O. Kitao, H. Nakai, T. Vreven, J. A. Montgomery, J. E. Peralta, F. Ogliaro, M. Bearpark, J. J. Heyd, E. Brothers, K. N. Kudin, V. N. Staroverov, T. Keith, R. Kobayashi, J. Normand, K. Raghavachari, A. Rendell, J. C. Knox, J. B. Cross, V. Bakken, C. Adamo, J. Jaramillo, R. Gomperts, R. E. Stratmann, O. Yazyev, A. J. Austin, R. Cammi, C. Pomelli, J. W. Ochterski, R. L. Martin, K. Morokuma, V. G. Zakrzewski, G. A. Voth, P. Salvador, J. J. Dannenberg, S. Dapprich, A. D. Daniels, O. Farkas, J. B. Foresman, J. V. Ortiz, J. Cioslowski, D. J. Fox, Gaussian Inc., Wallingford CT, 2010.

[19] J. B. Foresman, A Guide to Using Gaussian, Pittsburg, PA, in E: Frisch (Ed.), Exploring Chemistry with Electronic Structure Methods, 1996.

[20] J. M. L. Martin, C. Van Alsenoy, GAR2PED, A Program to obtain a potential energy distribution from a Gaussian archive record, University of Antwerp, Belgium, 2007.

[21] R. Dennington, T. Keith, J. Millam, Gaussview, Version 5, Semichem Inc., Shawnee Missions KS, 2009.

[22] A. D. Bochevarov, E. Harder, T. F. Hughes, J. R. Greenwood, D. A. Braden, D. M. Philipp, D. Rinaldo, M. D. Halls, J. Zhang, R. A. Friesner, Jaguar: a high-performance quantum chemistry software program with strengths in life and material sciences, Int. J. Quantum Chem. 113(18) (2013) 2110-2142.

[23] D. Shivakumar, J. Williams, Y. Wu, W. Damm, J. Shelley, W. Sherman, prediction of absolute solvation free energies using molecular dynamics free energy perturbation and the OPLS force field, J. Chem. Theory Comput. 6(2010) 1509-1519.

[24] J.L. Banks, H.S. Beard, Y. Cao, A.E. Cho, W. Damm, R. Farid, A.K. Felts, T.A. Halgren, D.T. Mainz, J.R. Maple, Integrated modeling program, applied chemical theory (IMPACT), J. Comput. Chem. 26 (16) (2005) 1752-1780.

[25] Schrödinger Release 2015-4: Maestro, version 10.4, Schrödinger, LLC, New York, NY, 2015. 2015.

[26] T. Joseph, H. T. Varghese, C. Y. Panicker, K. Viswanathan, M. Dolezal, C. Van Alsenoy, Spectroscopic (FT-IR, FT-Raman), first order hyperpolarizability, NBO analysis, HOMO and LUMO analysis of $\mathrm{N}$-[(4-(trifluoromethyl)phenyl]pyrazine-2-carboxamide by density functional methods, Arabian J. Chem. 10 (S2) S2281-S2294.

[27] W. He, G. Zhou, J. Li, A. Tian, Molecular design of analogues of 2,6-diamino-3,5dinitropyrazine-1-oxide, J. Mol. Struct. THEOCHEM 668 (2004) 201-208.

[28] N. P. G. Roeges, A Guide to the Complete Interpretation of Infrared Spectra of Organic Structures, Wiley, New York, 1994. 
[29] N. B. Colthup, L. H. Daly, S. E. Wiberly, Introduction to infrared and Raman spectroscopy, Ed. 2, Academic Press, New York, 1975.

[30] G. Varsanyi, Assignments of Vibrational Spectra of Seven Hundred Benzene Derivatives, Wiley, New York 1974.

[31] Y. S. Mary, C. Y. Panicker, H. T. Varghese, K. Raju, T. E. Bolelli, I. Yildiz, C. M. Granadeiro, H. I. S. Nogueiro, Vibrational spectroscopic studies and computational study of 4-fluoro- $N$-(2'-hydroxy-4'-nitrophenyl) phenylacetamide, J. Mol. Struct. 994 (2011) 223-231.

[32] M. Barthes, G. De Nunzio, M. Ribet, Polarons or proton transfer in chains of peptide groups, Synth. Met. 76 (1996) 337-340.

[33] J. Lukose, C.Y. Panicker, P.S. Nayak, B. Narayana, B.K. Sarojini, C. Van Alsenoy, A. A. Al-Saadi, Synthesis, structural and vibrational investigation on 2-phenyl- $N$-(pyrazine2-yl)acetamide combining XRD diffraction, FT-IR and NMR spectroscopies with DFT calculations, Spectrochim. Acta A 135 (2015) 608-616.

[34] E. Loh, Raman spectra of iodine derivatives of tyrosine and thyronine, J. Raman Spectrosc. 3 (1975) 327-333.

[35] R.A. Yadav, J. S. singh, O. Sala, The Raman and infrared spectra and normal coordinate analysis for 1,2-diiodotetraflurobenzene, J. Raman Spectrosc. 14 (1983) 353-357.

[36] D. A. Zainuri, S. Arshad, N. C. Khalib, I. A. Razak, R. R. Pillai, S. F. Sulaiman, N. S. Hashim, K. L. Ooi, S. Armaković, S. J. Armaković, C. Y. Panicker, synthesis, XRD crystal structure, spectroscopic characterization (FT-IR, 1H and 13C NMR), DFT studies, chemical reactivity and bond dissociation energy studies using molecular dynamics simulations and evaluation of antimicrobial and antioxidant activities of a novel chalcone derivative, (E)-1-(4-bromophenyl)-3-(4-iodophenyl)prop-2-en-1-one, J. Mol. Struct. 1128 (2017) 520-533.

[37] J. Coats, R. A. Meyers (Ed.), Encyclopedia of analytical chemistry, interpretation of Infrared spectra, a practical approach, in: John Wiley and Sons, Chichester, 2000.

[38] R. I. Al-Wabli, K. S. Resmi, Y. S. Mary, C. Y. Panicker, M. I. Attia, A. A. El-Emam, C. Van Alsenoy, Vibrational spectroscopic studies, Fukui functions, HOMO-LUMO, NLO, NBO analysis and molecular docking study of (E)-1-(1,3-benzodioxol-5-yl)-4,4dimethylpent-1-en-3-one, a potential precursor to bioactive agents, J. Mol. Struct. 1123 (2016) 375-383. 
[39] D. Philip, A. John, C.Y. Panicker, H.T. Varghese, FT-Raman, FT-IR and surface enhanced Raman scattering spectra of sodium salicylate, Spectrochim. Acta A 57 (2001) 1561-1566.

[40] J. F. Arenas, J. T. I. Navarrete, J. C. Ottero, J. I. Marcos, A. Cardenete, Vibrational spectra of $\left[{ }^{1} \mathrm{H}_{4}\right]$ pyrazine and $\left[{ }^{2} \mathrm{H}_{4}\right]$ pyrazine, J. Chem. Soc. Faraday Trans. 2 (81) (1985) 405415.

[41] NBO Version 3.1, E.D. Glendening, A.E. Reed, J.E. Carpenter, F. Weinhold.

[42] M. Adant, M. Dupuis, J. L. Bredas, Ab initio study of the nonlinear optical properties of urea: Electron correlation and dispersion effects, Int. J. Quantum. Chem. 56 (1995) 497507.

[43] A. S. El-Azab, Y. S. Mary, C. Y. Panicker, A. A.-M A-Aziz, A. Magda, El-Sherbeny, C. V. Alsenoy, DFT and experimental (FT-IR and FT-Raman) investigation of vibrational spectroscopy and molecular docking studies of 2-(4-oxo-3-phenyl-3,4dihydroquinazolin-2-ylthio)-N-(3,4,5 trimethoxy phenyl) acetamide, J. Mol Struct. 1113 (2016) 133-145.

[44] F. J. Luque, J. M. Lopez, M. Orozco, Perspective on electrostatic interactions of a solute with a continuum, a direct utilization of ab initio molecular potentials for the prevision of solvent effects, Theor. Chem. Acc. 103 (2000) 343-345.

[45] P. Politzer, J. S. Murray, in: D. L. Beveridge, R. Lavery, (Eds.), Theoretical Biochemistry and Molecular Biophysics, Springer, Berlin, 1991.

[46] J.S. Murray, J.M. Seminario, P. Politzer, P. Sjoberg, Average local ionization energies computed on the surfaces of some strained molecules, Int. J. Quantum Chem. 38(S24) (1990) 645-653.

[47] P. Politzer, F. Abu-Awwad, J.S. Murray, Comparison of density functional and Hartree-Fock average local ionization energies on molecular surfaces, Int. J. Quantum Chem. 69(4) (1998) 607-613.

[48] A. Toro-Labb_e, P. Jaque, J.S. Murray, P. Politzer, Connection between the average local ionization energy and the Fukui function, Chem. Phys. Lett. 407(2005) 143-146.

[49] R.G. Parr, Density Functional Theory of Atoms and Molecules, in Horizons of Quantum Chemistry, Springer, (1980) 5-15.

[50] A. Michalak, F. De Proft, P. Geerlings, R. Nalewajski, Fukui functions from the relaxed Kohn-Sham orbitals, J. Phys. Chem. A 103 (1999) 762-771.

[51] X. Ren, Y. Sun, X. Fu, L. Zhu, Z. Cui, DFT comparison of the OH-initiated degradation mechanisms for five chlorophenoxy herbicides, J. Mol. Model. 19 (2013) 2249-2263. 
[52] 1. Ai, J. Y. Liu, Mechanism of $\mathrm{OH}$-initiated atmospheric oxidation of E/Z-CF3CF= CFCF3: a quantum mechanical study, J. Mol. Model. 20 (2014) 1-10.

[53] W. Sang-aroon, V. Amornkitbamrung, V. Ruangpornvisuti, A density functional theory study on peptide bond cleavage at aspartic residues: direct vs cyclic intermediate hydrolysis, J. Mol. Model. 19 (2013) 5501-5513.

[54] J. Kieffer, É. Brémond, P. Lienard, G. Boccardi, In silico assessment of drug substances chemical stability, J. Mol. Struct. THEOCHEM. 954 (2010) 75-79.

[55] J.S. Wright, H. Shadnia, L.L. Chepelev, Stability of carbon-centered radicals: Effect of functional groups on the energetics of addition of molecular oxygen, J. Comput. Chem. 30 (2009) 1016-1026.

[56] P. Lienard, J. Gavartin, G. Boccardi, M. Meunier, Predicting drug substances autoxidation, Pharm. Res. 32(1) (2015) 300-310.

[57] T. Andersson, A. Broo, E. Evertsson, Prediction of Drug Candidates' Sensitivity Toward Autoxidation: Computational Estimation of $\mathrm{C} \square \mathrm{H}$ Dissociation Energies of Carbon-Centered Radicals, J. Pharm. Sci. 103(7) (2014) 1949-1955.

[58] R.V. Vaz, J.R. Gomes, C.M. Silva, Molecular dynamics simulation of diffusion coefficients and structural properties of ketones in supercritical CO 2 at infinite dilution, J. Supercritic. Fluids, 107 (2016) 630-638.

[59] D.J. Greenhalgh, A.C. Williams, P. Timmins, P. York, Solubility parameters as predictors of miscibility in solid dispersions, J. Pharm. Sci. 88 (1999) 1182-1190.

[60] R.C. Rowe, Adhesion of film coatings to tablet surfaces - a theoretical approach based on solubility parameters, Int. J. Pharm. 41 (1988) 219-222.

[61] R.C. Rowe, Interactions in coloured powders and tablet formulations: a theoretical approach based on solubility parameters, Int. J. Pharm. 53 (1989) 47-51.

[62] Lagunin, A.; Stepanchikova, A.; Filimonov, D.; Poroikov, V. "PASS: prediction of activity spectra for biologically active substances" Bioinformatics 16 (2000) 747-748.

[63] F. Tsuji, H. Aono, Role of Transient Receptor Potential Vanilloid 1 in Inflammation and Autoimmune Diseases, Pharmaceuticals (Basel). 5 (8) (2012) 837-852.

[64] F. Tsuji, M. Murai, K. Oki, Seki I, K. Ueda, H. Inoue, L. Nagelkerken, M. Sasano, H . Aono, Transient receptor potential vanilloid 1 agonists as candidates for antiinflammatory and immunomodulatory agents., Eur. J. Pharmacol. 627 (2010) 332-339.

[65] Y. K. C. D. Silva, C. V. Augusto, M. L. D. C. Barbosa, G. M. D. A. Melo, A. C. D. Queiroz, T. D. L. M. F. Dias, W. B. Júnior, E. J. Barreiro, L. M. Lima, M. S. A. Moreira, Synthesis and pharmacological evaluation of pyrazine $\mathrm{N}$-acylhydrazone derivatives 
designed as novel analgesic and anti-inflammatory drug candidates, Bioorganic and Medicinal Chemistry 18 (2010) 5007-5015.

[66] G. M. Morris, R. Huey, W. Lindstrom, M. F. Sanner, R. K. Belew, D. S. Goodsell, A. J. Olson, Autodock4 and AutoDockTools4: automated docking with selective receptor flexiblity. J. Computational Chemistry 16 (2009) 2785-2791.

[67] O. Trott, A. J. Olson, Auto Dock Vina: improving the speed and accuracy of docking with a new scoring function, efficient optimization and multi-threading J. Comput. Chem. 31 (2010) 455-461.

[68] G. M. Morris, D. S. Goodsell, R. S. Halliday, R. Huey, W. E. Hart, R. Belew, A. J. Olson, Automated docking using a Lamarckian genetic algorithm and an empirical binding free energy function, Journal of Computational Chemistry. 19 (1998) 1639-1662.

\section{Figure Caption}

Fig 1 FT-IR

Fig 2 FT-Raman

Fig 3 Molecule

Fig 4 HOMO-LUMO

Fig 5 MEP

Fig 6 ALIE

Fig 7 Fukui

Fig 8 BDE

Fig 9 RDF

Fig 10 Docking

Fig 11 Docking 


\section{Table Caption}

Table 1 Geometrical Parameters

Table 2 Frequency

Table 3 NBO-1

Table 4 NBO-2

Table 5 NLO of Substitution

Table 6 Halogen HOMO-LUMO

Table 7 Solubility parameter

Table 8 Pass Analysis

Table 9 Docking

\section{Graphical Abstract}
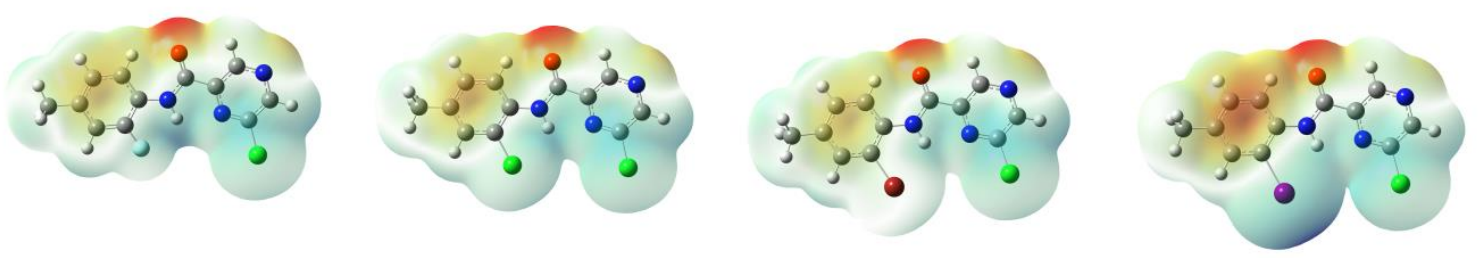


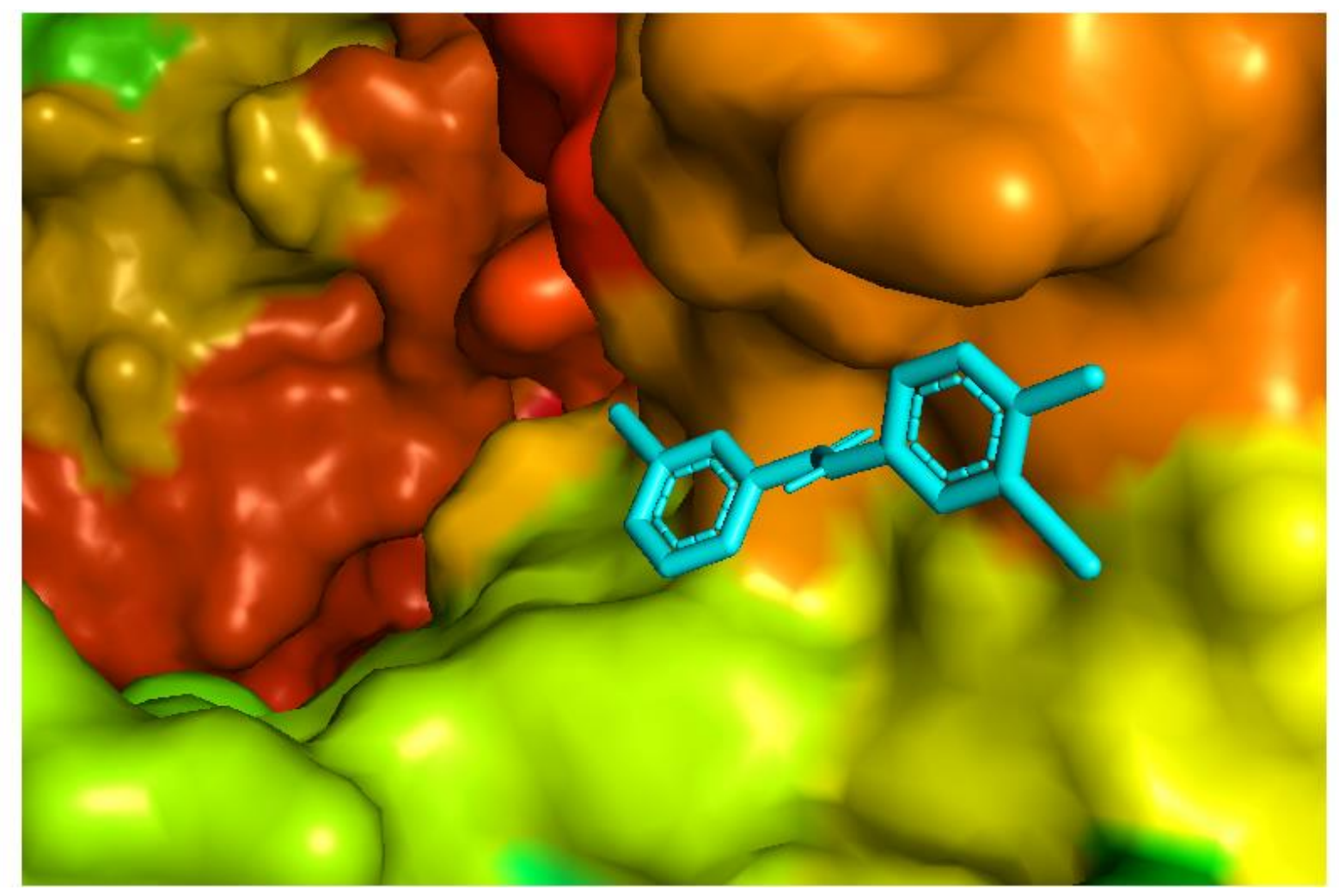


Figures

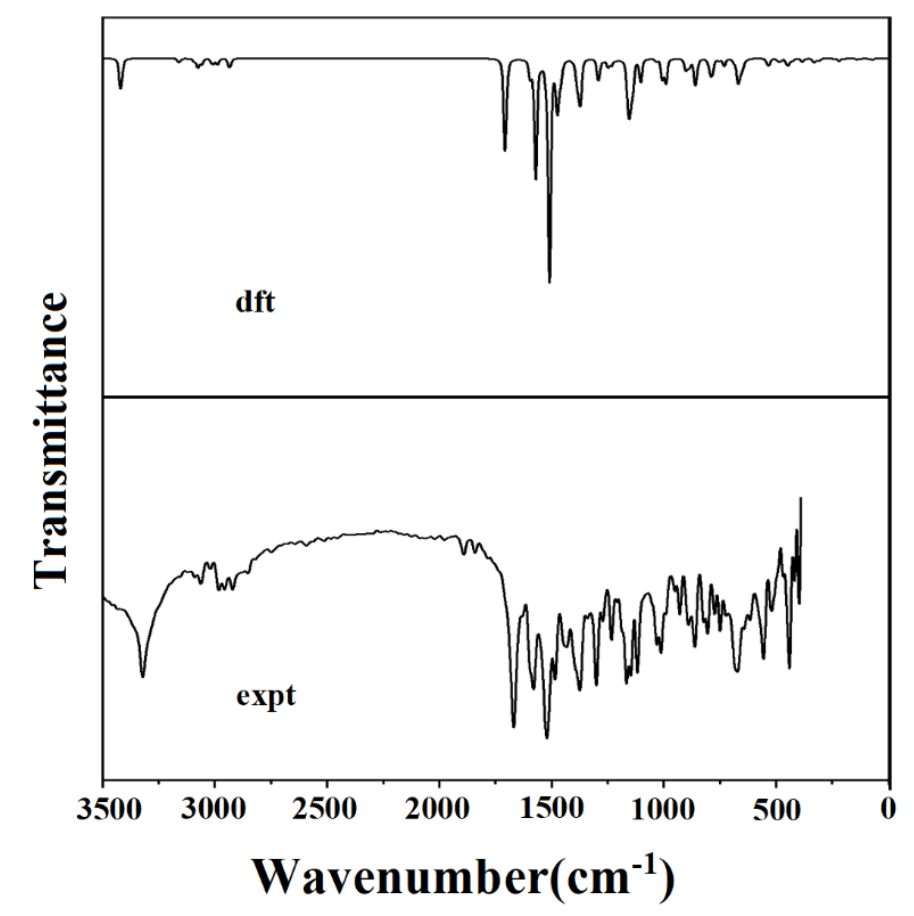

Fig. 1. FT-IR spectrum of CIMPPC 


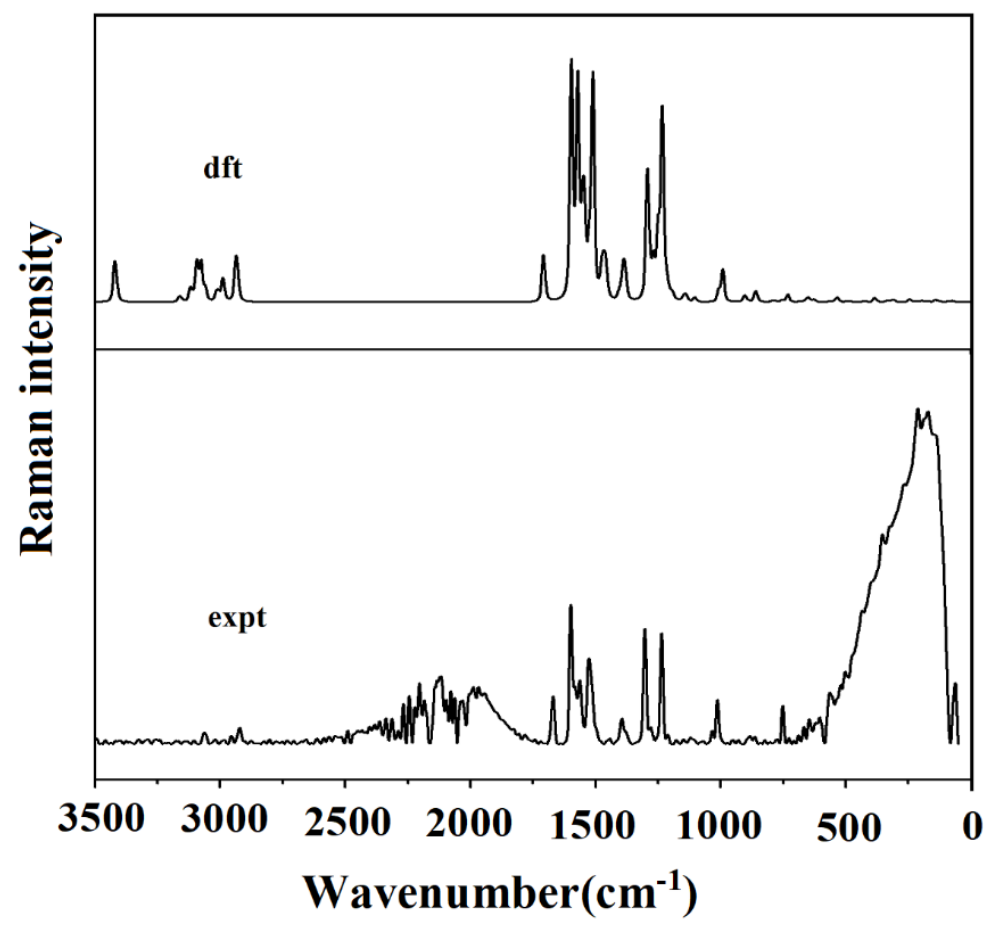

Fig. 2. FT-Raman spectrum of CIMPPC

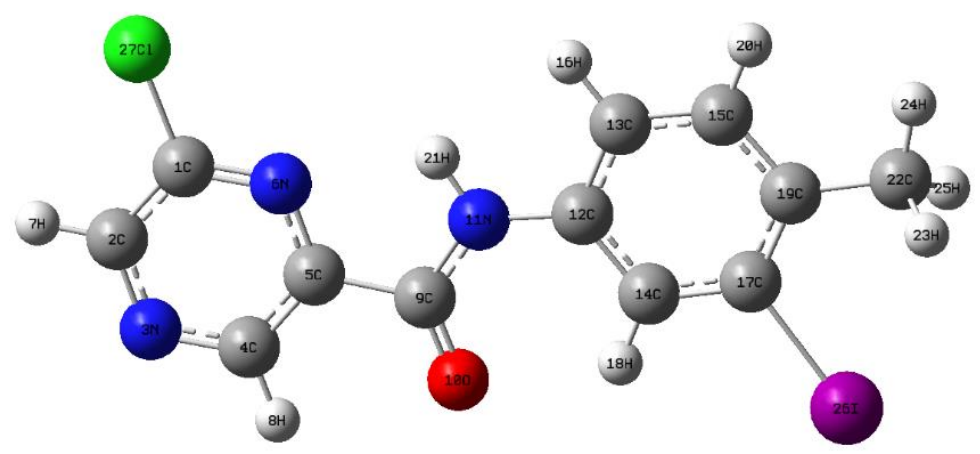

Fig. 3. Optimized geometry of CIMPPC 


\begin{tabular}{|c|c|c|c|c|c|}
\hline 98 & LUMO & ogese & LUMO & 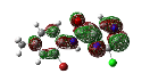 & LUMO \\
\hline & номо & & номо & ${ }_{16 \mathrm{Br}}$ & номо \\
\hline$\theta_{0}$ & LUMO & & LUMO & \% & LUMO \\
\hline & номо & & номо & $18 \mathrm{Br}$ & номо \\
\hline$\infty$ & LUMO & & LUMO & & LUMO \\
\hline${ }_{20 F}$ & НОМо & ${ }_{20 \mathrm{Cl}}$ & номо & $\underset{20 \mathrm{Br}}{3}$ & Номо \\
\hline & LUMO & & LUMO & & LUMO \\
\hline & номо & & НОМо & & НОМо \\
\hline
\end{tabular}

Fig. 4. HOMO, LUMO plots of CIMPPC with halogen substitutions 


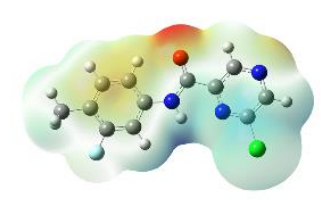

20F

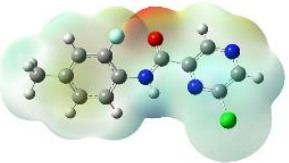

18F

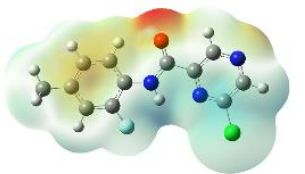

$16 \mathrm{~F}$

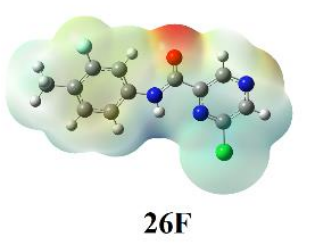

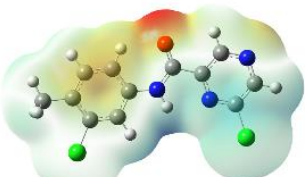

$20 \mathrm{Cl}$

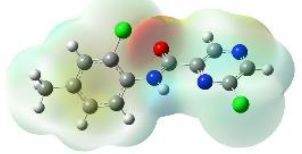

$18 \mathrm{CI}$

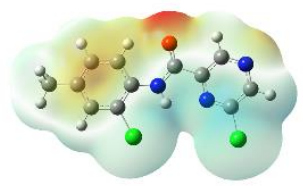

16CI

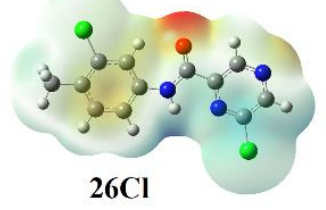

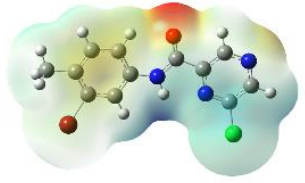

$20 \mathrm{Br}$

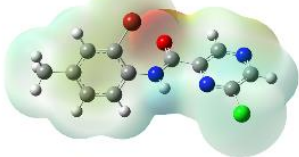

$18 B r$
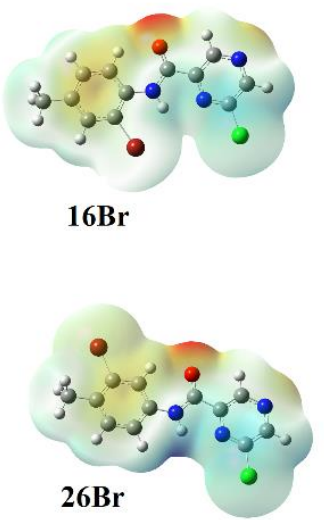

Fig. 5. MEP plots of CIMPPC with halogen substitutions 


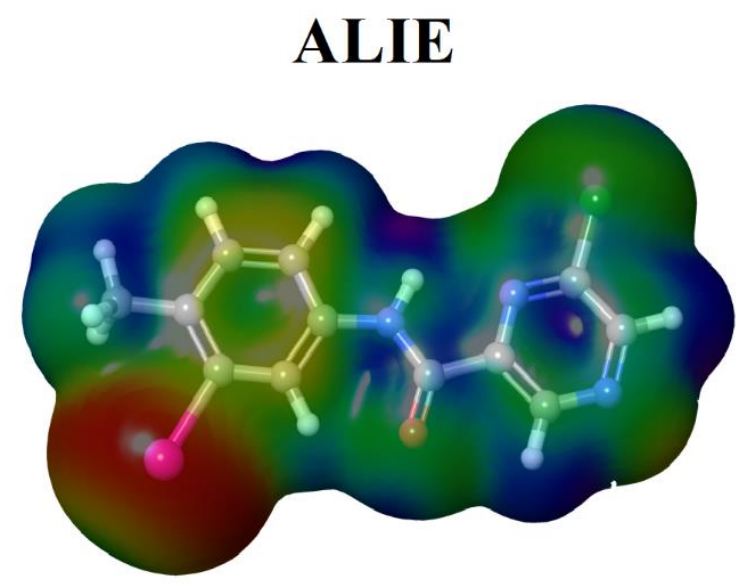

179.47 ALIE [Kcal/mol] 332.15

\section{Fig. 6. ALIE surface of CIMPPC}

$$
f^{+}
$$

a)

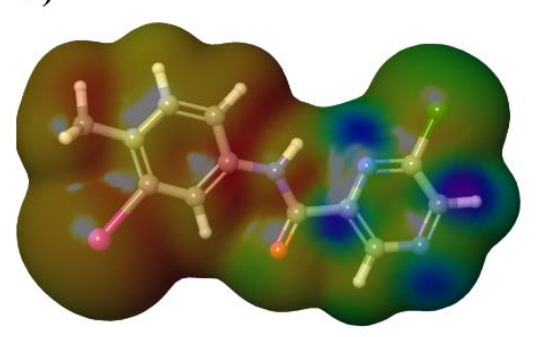

$-1.74 \times 10^{-5} 5.36 \times 10^{-4}$ b)

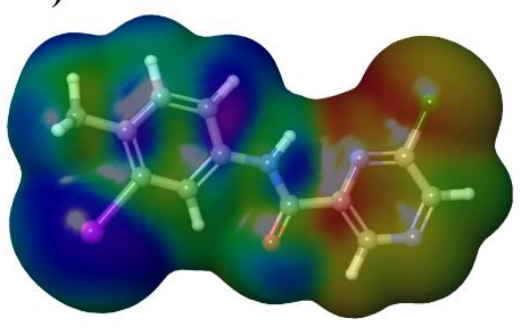

$-2.68 \times 10^{-5} \quad 2.76 \times 10^{-4}$

Fig. 7. Fukui functions a) $f^{+}$and b) $f^{-}$of the CIMPPC 


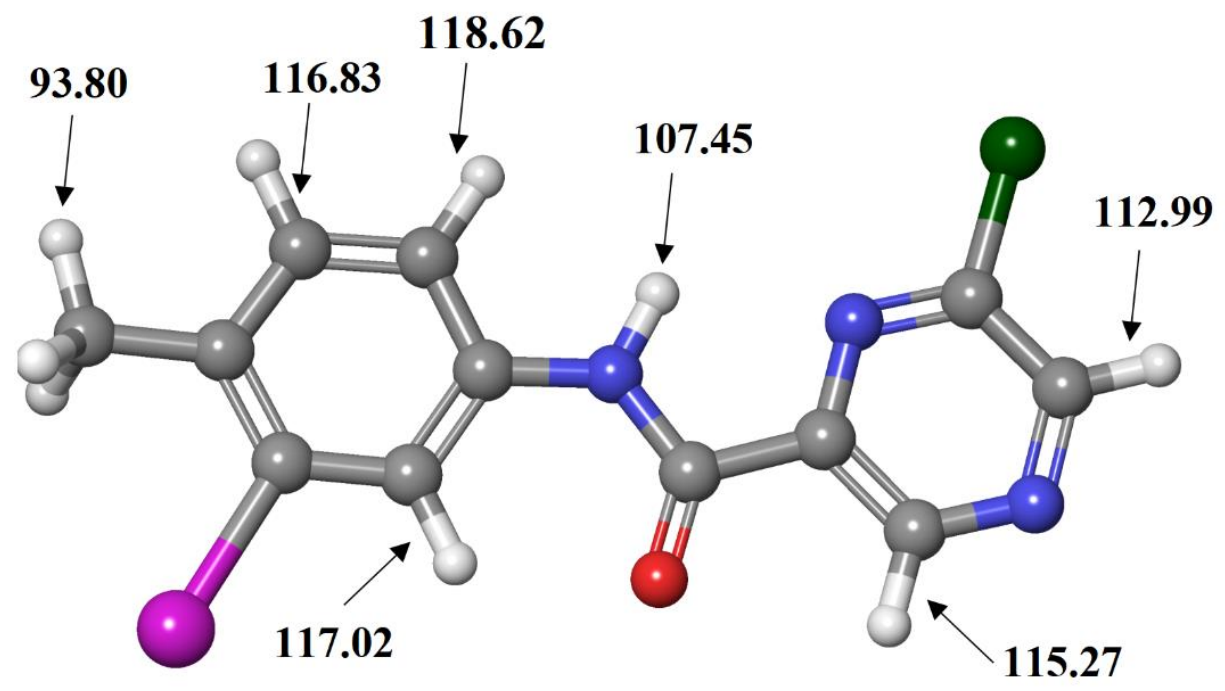

Fig. 8. BDEs of all single acyclic bonds of CIMPPC

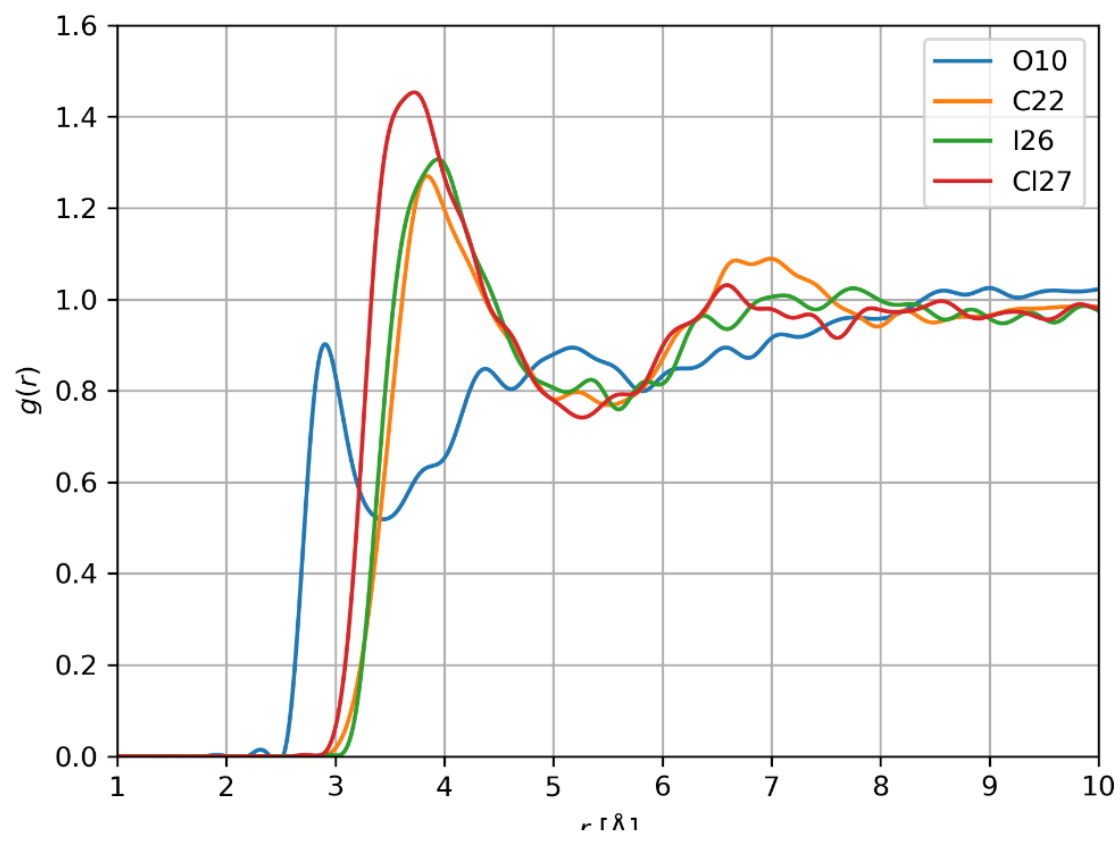

Fig. 9. RDFs of CIMPPC atoms with significant interactions with water molecules 


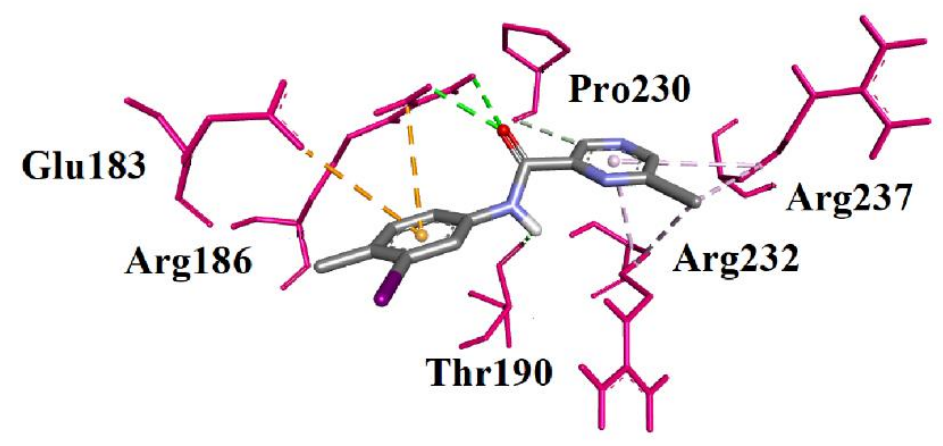

Fig. 10. Interactive plots of amino acids of the receptor with the ligand

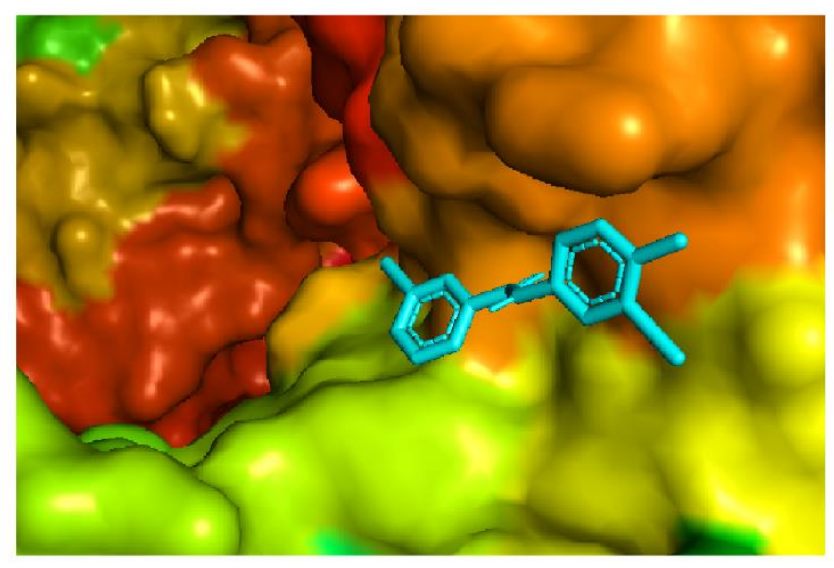

Fig. 11. The docked ligand of CIMPPC at the active site of the receptor 
Tables

Table 1

Optimized Geometrical parameters of 6-chloro-N-(3-iodo-4-methyl phenyl) pyrazine-2carboxamide.

\begin{tabular}{|c|c|c|c|c|c|}
\hline \multicolumn{2}{|c|}{ Bond length $(\AA)$} & \multicolumn{2}{|c|}{ Bond angles $\left({ }^{\circ}\right)$} & \multicolumn{2}{|c|}{ Dihedral angles $\left({ }^{\circ}\right)$} \\
\hline $\mathrm{C}_{1}-\mathrm{C}_{2}$ & 1.4038 & $\mathrm{C}_{2}-\mathrm{C}_{1}-\mathrm{N}_{6}$ & 122.4 & $\mathrm{~N}_{6}-\mathrm{C}_{1}-\mathrm{C}_{2}-\mathrm{C}_{3}$ & 0.0 \\
\hline $\mathrm{C}_{1}-\mathrm{N}_{6}$ & 1.3185 & $\mathrm{C}_{2}-\mathrm{C}_{1}-\mathrm{Cl}_{27}$ & 119.6 & $\mathrm{~N}_{6}-\mathrm{C}_{1}-\mathrm{C}_{2}-\mathrm{C}_{7}$ & -180.0 \\
\hline $\mathrm{C}_{1}-\mathrm{Cl}_{27}$ & 1.7509 & $\mathrm{C}_{1}-\mathrm{C}_{2}-\mathrm{C}_{3}$ & 120.8 & $\mathrm{Cl}_{27}-\mathrm{C}_{1}-\mathrm{C}_{2}-\mathrm{C}_{3}$ & -180.0 \\
\hline $\mathrm{C}_{2}-\mathrm{N}_{3}$ & 1.3318 & $\mathrm{C}_{1}-\mathrm{C}_{2}-\mathrm{H}_{7}$ & 121.0 & $\mathrm{C}_{2}-\mathrm{C}_{1}-\mathrm{N}_{6}-\mathrm{C}_{5}$ & -0.0 \\
\hline $\mathrm{C}_{2}-\mathrm{H}_{7}$ & 1.0864 & $\mathrm{~N}_{6}-\mathrm{C}_{1}-\mathrm{Cl}_{27}$ & 118.0 & $\mathrm{Cl}_{27}-\mathrm{C}_{1}-\mathrm{N}_{6}-\mathrm{C}_{5}$ & -180.0 \\
\hline $\mathrm{N}_{3}-\mathrm{C}_{4}$ & 1.3394 & $\mathrm{C}_{1}-\mathrm{N}_{6}-\mathrm{C}_{5}$ & 116.8 & $\mathrm{C1}_{27}-\mathrm{C}_{2}-\mathrm{C}_{3}-\mathrm{C}_{4}$ & -0.0 \\
\hline $\mathrm{C}_{4}-\mathrm{C}_{5}$ & 1.3971 & $\mathrm{C}_{3}-\mathrm{C}_{2}-\mathrm{H}_{7}$ & 118.2 & $\mathrm{C}_{2}-\mathrm{C}_{3}-\mathrm{C}_{4}-\mathrm{C}_{5}$ & -0.0 \\
\hline $\mathrm{C}_{4}-\mathrm{H}_{8}$ & 1.0848 & $\mathrm{C}_{2}-\mathrm{C}_{3}-\mathrm{C}_{4}$ & 117.3 & $\mathrm{C}_{3}-\mathrm{C}_{4}-\mathrm{C}_{5}-\mathrm{N}_{6}$ & 0.0 \\
\hline $\mathrm{C}_{5}-\mathrm{N}_{6}$ & 1.3440 & $\mathrm{C}_{3}-\mathrm{C}_{4}-\mathrm{C}_{5}$ & 121.5 & $\mathrm{C}_{3}-\mathrm{C}_{4}-\mathrm{C}_{5}-\mathrm{C}_{9}$ & -180.0 \\
\hline $\mathrm{C}_{5}-\mathrm{C}_{9}$ & 1.5094 & $\mathrm{C}_{3}-\mathrm{C}_{4}-\mathrm{H}_{8}$ & 118.2 & $\mathrm{C}_{4}-\mathrm{C}_{5}-\mathrm{N}_{6-}-\mathrm{Cl}_{27}$ & -0.0 \\
\hline $\mathrm{C}_{9}-\mathrm{O}_{10}$ & 1.2267 & $\mathrm{C}_{5}-\mathrm{C}_{4}-\mathrm{H}_{8}$ & 120.3 & $\mathrm{C}_{9}-\mathrm{C}_{5}-\mathrm{N}_{6}-\mathrm{C}_{1}$ & 180.0 \\
\hline $\mathrm{C}_{9}-\mathrm{N}_{11}$ & 1.3657 & $\mathrm{C}_{4}-\mathrm{C}_{5}-\mathrm{N}_{6}$ & 121.2 & $\mathrm{C}_{4}-\mathrm{C}_{5}-\mathrm{C}_{9}-\mathrm{O}_{10}$ & 0.0 \\
\hline $\mathrm{N}_{11}-\mathrm{C}_{12}$ & 1.4074 & $\mathrm{C}_{4}-\mathrm{C}_{5}-\mathrm{C}_{9}$ & 120.0 & $\mathrm{C}_{4}-\mathrm{C}_{5}-\mathrm{C}_{9}-\mathrm{N}_{11}$ & -180.0 \\
\hline $\mathrm{N}_{11}-\mathrm{H}_{21}$ & 1.0152 & $\mathrm{~N}_{6}-\mathrm{C}_{5}-\mathrm{C}_{9}$ & 118.8 & $\mathrm{~N}_{6}-\mathrm{C}_{5}-\mathrm{C}_{9}-\mathrm{O}_{10}$ & -180.0 \\
\hline $\mathrm{C}_{12}-\mathrm{C}_{13}$ & 1.4014 & $\mathrm{C}_{5}-\mathrm{C}_{9}-\mathrm{O}_{10}$ & 120.5 & $\mathrm{~N}_{6}-\mathrm{C}_{5}-\mathrm{C}_{9}-\mathrm{N}_{11}$ & 0.0 \\
\hline $\mathrm{C}_{12}-\mathrm{C}_{14}$ & 1.4030 & $\mathrm{C}_{5}-\mathrm{C}_{9}-\mathrm{N}_{11}$ & 113.2 & $\mathrm{C}_{5}-\mathrm{C}_{9}-\mathrm{N}_{11}-\mathrm{C}_{12}$ & -180.0 \\
\hline $\mathrm{C}_{13}-\mathrm{C}_{15}$ & 1.3890 & $\mathrm{C}_{10}-\mathrm{C}_{9}-\mathrm{N}_{11}$ & 126.4 & $\mathrm{O}_{10}-\mathrm{C}_{9}-\mathrm{N}_{11}-\mathrm{C}_{12}$ & 0.0 \\
\hline $\mathrm{C}_{13}-\mathrm{H}_{16}$ & 1.0875 & $\mathrm{C}_{9}-\mathrm{N}_{11}-\mathrm{C}_{12}$ & 128.8 & $\mathrm{C}_{9}-\mathrm{N}_{11}-\mathrm{C}_{12}-\mathrm{C}_{13}$ & 180.0 \\
\hline $\mathrm{C}_{14}-\mathrm{C}_{17}$ & 1.3927 & $\mathrm{C}_{9}-\mathrm{N}_{11}-\mathrm{H}_{21}$ & 114.3 & $\mathrm{C}_{9}-\mathrm{N}_{11}-\mathrm{C}_{12}-\mathrm{C}_{14}$ & -0.0 \\
\hline $\mathrm{C}_{14}-\mathrm{H}_{18}$ & 1.0875 & $\mathrm{C}_{12}-\mathrm{N}_{11}-\mathrm{H}_{21}$ & 116.9 & $\mathrm{~N}_{11}-\mathrm{C}_{12}-\mathrm{C}_{13}-\mathrm{C}_{15}$ & -180.0 \\
\hline $\mathrm{C}_{15}-\mathrm{C}_{19}$ & 1.4043 & $\mathrm{C}_{11}-\mathrm{C}_{12}-\mathrm{C}_{13}$ & 117.8 & $\mathrm{C}_{14}-\mathrm{C}_{12}-\mathrm{C}_{13}-\mathrm{C}_{15}$ & 0.0 \\
\hline $\mathrm{C}_{15}-\mathrm{H}_{20}$ & 1.0869 & $\mathrm{C}_{11}-\mathrm{C}_{12}-\mathrm{C}_{14}$ & 122.9 & $\mathrm{~N}_{11}-\mathrm{C}_{12}-\mathrm{C}_{14}-\mathrm{C}_{17}$ & 180.0 \\
\hline $\mathrm{C}_{17}-\mathrm{C}_{19}$ & 1.4018 & $\mathrm{C}_{13}-\mathrm{C}_{12}-\mathrm{C}_{14}$ & 119.3 & $\mathrm{C}_{13}-\mathrm{C}_{12}-\mathrm{C}_{14}-\mathrm{C}_{17}$ & -0.0 \\
\hline $\mathrm{C}_{17}-\mathrm{I}_{26}$ & 2.1547 & $\mathrm{C}_{12}-\mathrm{C}_{13}-\mathrm{C}_{15}$ & 120.1 & $\mathrm{C}_{12}-\mathrm{C}_{13}-\mathrm{C}_{15}-\mathrm{C}_{19}$ & -0.0 \\
\hline $\mathrm{C}_{19}-\mathrm{C}_{22}$ & 1.5075 & $\mathrm{C}_{12}-\mathrm{C}_{13}-\mathrm{H}_{16}$ & 120.0 & $\mathrm{C}_{12}-\mathrm{C}_{14}-\mathrm{C}_{17}-\mathrm{C}_{19}$ & -0.0 \\
\hline $\mathrm{C}_{22}-\mathrm{H}_{23}$ & 1.0964 & $\mathrm{C}_{12}-\mathrm{C}_{14}-\mathrm{C}_{17}$ & 119.0 & $\mathrm{C}_{12}-\mathrm{C}_{14}-\mathrm{C}_{17}-\mathrm{I}_{26}$ & -180.0 \\
\hline $\mathrm{C}_{22}-\mathrm{H}_{24}$ & 1.0942 & $\mathrm{C}_{12}-\mathrm{C}_{14}-\mathrm{H}_{18}$ & 119.5 & $\mathrm{C}_{13}-\mathrm{C}_{15}-\mathrm{C}_{19}-\mathrm{C}_{17}$ & -0.0 \\
\hline $\mathrm{C}_{22}-\mathrm{H}_{25}$ & 1.0964 & $\mathrm{C}_{15}-\mathrm{C}_{13}-\mathrm{C}_{16}$ & 119.9 & $\mathrm{C}_{13}-\mathrm{C}_{15}-\mathrm{C}_{19}-\mathrm{C}_{22}$ & 180.0 \\
\hline & & $\mathrm{C}_{13}-\mathrm{C}_{15}-\mathrm{C}_{19}$ & 122.4 & $\mathrm{C}_{14}-\mathrm{C}_{17}-\mathrm{C}_{19}-\mathrm{C}_{15}$ & 0.0 \\
\hline & & $\mathrm{C}_{13}-\mathrm{C}_{15}-\mathrm{H}_{20}$ & 119.0 & $\mathrm{C}_{14}-\mathrm{C}_{17}-\mathrm{C}_{19}-\mathrm{C}_{22}$ & 180.0 \\
\hline & & $\mathrm{C}_{17}-\mathrm{C}_{14}-\mathrm{H}_{18}$ & 121.6 & $\mathrm{I}_{26}-\mathrm{C}_{17}-\mathrm{C}_{19}-\mathrm{C}_{15}$ & 180.0 \\
\hline & & $\mathrm{C}_{14}-\mathrm{C}_{17}-\mathrm{C}_{19}$ & 123.4 & $\mathrm{I}_{26}-\mathrm{C}_{17}-\mathrm{C}_{19}-\mathrm{C}_{22}$ & 0.0 \\
\hline & & $\mathrm{C}_{14}-\mathrm{C}_{17}-\mathrm{I}_{26}$ & 116.4 & & \\
\hline & & $\mathrm{C}_{19}-\mathrm{C}_{15}-\mathrm{H}_{20}$ & 118.6 & & \\
\hline & & $\mathrm{C}_{15}-\mathrm{C}_{19}-\mathrm{C}_{17}$ & 115.9 & & \\
\hline & & $\mathrm{C}_{15}-\mathrm{C}_{19}-\mathrm{C}_{22}$ & 120.2 & & \\
\hline & & $\mathrm{C}_{19}-\mathrm{C}_{17-\mathrm{I}_{26}}$ & 120.2 & & \\
\hline & & $\mathrm{C}_{17}-\mathrm{C}_{19}-\mathrm{C}_{22}$ & 123.9 & & \\
\hline & & $\mathrm{C}_{19}-\mathrm{C}_{22}-\mathrm{H}_{23}$ & 111.5 & & \\
\hline
\end{tabular}




\begin{tabular}{|l|l|l|l|l|l|}
\hline & & $\mathrm{C}_{19}-\mathrm{C}_{22}-\mathrm{H}_{24}$ & 110.6 & & \\
\hline & & $\mathrm{C}_{19}-\mathrm{C}_{22}-\mathrm{H}_{25}$ & 111.5 & & \\
\hline & $\mathrm{H}_{23}-\mathrm{C}_{22}-\mathrm{H}_{24}$ & 108.1 & & \\
\hline & $\mathrm{H}_{23}-\mathrm{C}_{22}-\mathrm{H}_{25}$ & 106.8 & & \\
\hline & & $\mathrm{H}_{24}-\mathrm{C}_{22}-\mathrm{H}_{25}$ & 108.1 & & \\
\hline
\end{tabular}

\section{Table 2}

Calculated scaled wavenumbers, observed IR, Raman bands and vibrational assignments with potential energy distribution (PED) of the title compound.

\begin{tabular}{|c|c|c|c|c|c|c|}
\hline \multicolumn{4}{|c|}{ B3LYP/gen } & \multirow[t]{2}{*}{$\operatorname{IR}\left(\mathrm{cm}^{-1}\right)$} & \multirow[t]{2}{*}{$\operatorname{Raman}\left(\mathrm{cm}^{-1}\right)$} & \multirow[t]{2}{*}{ Assignments $^{\mathrm{a}}$} \\
\hline$v\left(\mathrm{~cm}^{-1}\right)^{\mathrm{b}}$ & $v\left(\mathrm{~cm}^{-1}\right)^{\mathrm{c}}$ & $\mathrm{IR}_{\mathrm{I}}$ & $\mathrm{R}_{\mathrm{A}}$ & & & \\
\hline 3556 & 3418 & 76.90 & 247.15 & 3330 & 3494 & $v \mathrm{NH}(91)$ \\
\hline 3286 & 3159 & 10.23 & 29.34 & - & - & vCHPh(99) \\
\hline 3241 & 3116 & 0.48 & 70.55 & - & - & vCHPz(99) \\
\hline 3217 & 3093 & 4.95 & 146.37 & - & - & vCHPz(99) \\
\hline 3200 & 3077 & 17.56 & 159.69 & - & - & vCHPh(99) \\
\hline 3182 & 3059 & 11.72 & 51.55 & 3062 & 3063 & vCHPh(99) \\
\hline 3131 & 3010 & 16.98 & 72.38 & 3024 & - & $\mathrm{vCH}_{3}(79)$ \\
\hline 3107 & 2987 & 12.08 & 99.59 & 2982 & 2957 & $v \mathrm{CH}_{3}(78)$ \\
\hline 3052 & 2934 & 24.50 & 261.06 & 2925 & 2924 & $\mathrm{vCH}_{3}(93)$ \\
\hline 1775 & 1706 & 198.96 & 153.36 & 1670 & 1667 & $v \mathrm{CO}(66)$ \\
\hline 1660 & 1596 & 29.42 & 617.65 & 1580 & 1598 & $v \operatorname{Ph}(54), \delta \mathrm{CHPh}(14)$ \\
\hline 1635 & 1571 & 239.88 & 635.27 & - & 1561 & $v \operatorname{Ph}(42), \delta \mathrm{NH}(15)$ \\
\hline 1610 & 1548 & 11.57 & 477.37 & - & - & $v \mathrm{Pz}(69), \delta \mathrm{CHPz}(19)$ \\
\hline 1584 & 1523 & 38.45 & 203.67 & 1520 & 1525 & $v \operatorname{Pz}(75)$ \\
\hline 1570 & 1509 & 391.56 & 550.79 & - & - & $\delta \mathrm{NH}(34), v \mathrm{Ph}(27)$ \\
\hline 1536 & 1476 & 95.98 & 74.90 & 1485 & - & $v \mathrm{Ph}(39), v \mathrm{CHPh}(31)$ \\
\hline 1521 & 1462 & 64.19 & 173.43 & - & - & $\delta \mathrm{CH}_{3}(75)$ \\
\hline 1512 & 1453 & 6.12 & 19.35 & 1433 & - & $\delta \mathrm{CH}_{3}(95)$ \\
\hline 1463 & 1406 & 2.18 & 17.01 & - & 1395 & $v \mathrm{Pz}(41), \delta \mathrm{CHPz}(28)$ \\
\hline 1449 & 1392 & 1.03 & 33.04 & 1377 & - & $\delta \mathrm{CH}_{3}(62), v \mathrm{C}_{19} \mathrm{C}_{22}(19)$ \\
\hline 1440 & 1384 & 70.36 & 153.67 & - & - & $\delta \mathrm{CHPz}(43), v \mathrm{Pz}(14), v \mathrm{Ph}(10)$ \\
\hline 1428 & 1373 & 83.38 & 1.72 & - & - & $v \mathrm{Ph}(26), \delta \mathrm{CHPz}(22), v \mathrm{CHPh}(16)$ \\
\hline 1343 & 1291 & 51.05 & 422.73 & 1298 & 1302 & $v \operatorname{Ph}(69)$ \\
\hline 1320 & 1269 & 3.80 & 100.71 & - & - & $\delta \mathrm{CHPh}(39)$ \\
\hline 1298 & 1248 & 17.99 & 199.57 & - & - & $\delta \mathrm{CHPh}(25), v_{5} \mathrm{C}_{9}(17), v \mathrm{Pz}(13)$ \\
\hline 1281 & 1232 & 9.95 & 458.13 & 1230 & 1237 & $v \mathrm{CN}(28), v \mathrm{Ph}(21), \delta \mathrm{CN}(14)$ \\
\hline 1261 & 1212 & 4.22 & 46.39 & - & - & $v \mathrm{Pz}(81)$ \\
\hline 1241 & 1193 & 2.75 & 26.02 & 1166 & 1179 & $\delta \mathrm{CHPh}(29), v \operatorname{Ph}(13), \delta \mathrm{Ph}(11)$ \\
\hline 1204 & 1158 & 139.97 & 3.37 & 1147 & - & $\delta \mathrm{CHPz}(36), v \mathrm{Pz}(34), \delta \mathrm{Pz}(13), v \mathrm{Ph}(11)$ \\
\hline 1191 & 1145 & 29.06 & 6.05 & - & - & $v \mathrm{Pz}(27), \delta \mathrm{CHPh}(22)$ \\
\hline 1186 & 1140 & 59.64 & 19.73 & 1121 & 1118 & $v \mathrm{Pz}(24), \delta \mathrm{CHPh}(22), \delta \mathrm{CHPz}(17)$ \\
\hline
\end{tabular}




\begin{tabular}{|c|c|c|c|c|c|c|}
\hline 1148 & 1103 & 42.21 & 9.99 & - & - & $v \mathrm{CN}(26), v \mathrm{Pz}(22)$ \\
\hline 1075 & 1033 & 4.17 & 0.19 & 1031 & 1035 & $\delta \mathrm{CH}_{3}(89)$ \\
\hline 1047 & 1007 & 35.55 & 23.23 & 1009 & 1015 & $\delta \mathrm{Ph}(43), v \operatorname{Ph}(27)$ \\
\hline 1031 & 991 & 42.31 & 70.72 & - & - & $v \operatorname{Pz}(62), \delta \mathrm{Pz}(55)$ \\
\hline 1029 & 989 & 3.85 & 9.31 & - & - & $\delta \mathrm{CH}_{3}(70)$ \\
\hline 981 & 943 & 0.89 & 1.42 & - & 958 & $\gamma \mathrm{CHPz}(88)$ \\
\hline 945 & 908 & 0.75 & 2.02 & 926 & - & $\gamma \mathrm{CHPh}(91)$ \\
\hline 938 & 902 & 21.17 & 16.0 & 889 & 886 & $\delta \mathrm{CN}(21), v \mathrm{C}_{9} \mathrm{C}_{5}(16), \delta \mathrm{Pz}(13), v \mathrm{CCl}(11)$ \\
\hline 926 & 890 & 14.86 & 1.18 & - & - & $\gamma \mathrm{CHPh}(79)$ \\
\hline 919 & 884 & 8.28 & 0.06 & - & - & $\gamma \mathrm{CHPz}(73)$ \\
\hline 892 & 858 & 62.66 & 32.03 & 862 & 866 & $v \mathrm{Ph}(21), \delta \mathrm{Ph}(15)$ \\
\hline 826 & 794 & 29.54 & 3.18 & - & - & $\gamma \mathrm{CHPh}(79)$ \\
\hline 817 & 785 & 27.42 & 2.56 & 776 & - & $\delta \mathrm{CO}(20), \delta \mathrm{Pz}(20)$ \\
\hline 784 & 753 & 4.92 & 5.54 & 749 & 749 & $\delta \mathrm{Pz}(39), \gamma \mathrm{C}_{5} \mathrm{C}_{9}(27), \gamma \mathrm{CO}(27)$ \\
\hline 761 & 732 & 13.78 & 16.72 & 723 & - & $\delta \mathrm{Ph}(23), v \mathrm{C}_{19} \mathrm{C}_{22}(23), \delta \mathrm{Pz}(10)$ \\
\hline 735 & 707 & 0.44 & 0.20 & - & - & $\gamma \mathrm{Pz}(56), \delta \mathrm{CO}(17)$ \\
\hline 712 & 685 & 8.56 & 1.35 & - & 691 & $\gamma \mathrm{Ph}(74)$ \\
\hline 694 & 667 & 63.76 & 1.63 & 674 & 668 & $\gamma \mathrm{NH}(44), \gamma \mathrm{CO}(29)$ \\
\hline 676 & 650 & 25.67 & 14.45 & 644 & 648 & $\delta \mathrm{Ph}(70)$ \\
\hline 654 & 629 & 1.18 & 6.23 & 614 & 603 & $\delta \mathrm{Pz}(66)$ \\
\hline 584 & 562 & 0.03 & 2.34 & 550 & 566 & $\gamma \mathrm{Ph}(30), \gamma \mathrm{C}_{19} \mathrm{C}_{22}(12)$ \\
\hline 556 & 535 & 20.34 & 14.29 & 516 & 504 & $\gamma \mathrm{CO}(28), \delta \mathrm{Ph}(22)$ \\
\hline 518 & 498 & 1.25 & 0.95 & - & - & $\gamma \mathrm{CCl}(35), \gamma \mathrm{Pz}(24), \gamma \mathrm{CO}(10)$ \\
\hline 504 & 485 & 9.43 & 2.57 & - & - & $\delta \mathrm{Ph}(27), \delta \mathrm{Pz}(26), v \mathrm{C}_{9} \mathrm{C}_{5}(12)$ \\
\hline 467 & 449 & 20.88 & 0.24 & 441 & 435 & $\gamma \mathrm{Pz}(63), \gamma \mathrm{C}_{5} \mathrm{C}_{9}(15)$ \\
\hline 447 & 430 & 4.74 & 0.67 & - & - & $\gamma \mathrm{Ph}(62)$ \\
\hline 440 & 423 & 0.74 & 1.92 & 396 & - & $\delta \mathrm{C}_{19} \mathrm{C}_{22}(35), \delta \mathrm{CN}(16)$ \\
\hline 398 & 383 & 7.11 & 8.94 & 366 & - & $v \operatorname{CCl}(39), \delta \mathrm{Pz}(18)$ \\
\hline 351 & 337 & 0.49 & 2.24 & 357 & 354 & $\gamma \mathrm{C}_{19} \mathrm{C}_{22}(35), \gamma \mathrm{Ph}(25)$ \\
\hline 344 & 330 & 9.25 & 1.33 & - & - & $\gamma \mathrm{CO}(36), \delta \mathrm{CN}(23)$ \\
\hline 323 & 311 & 6.34 & 7.57 & - & 271 & $v \mathrm{CI}(30), \delta \mathrm{CCl}(26)$ \\
\hline 254 & 244 & 0.89 & 6.23 & - & - & $\delta \mathrm{Ph}(18), v \mathrm{C}_{5} \mathrm{C}_{9}(11)$ \\
\hline 230 & 221 & 5.28 & 1.22 & - & 211 & $v \mathrm{CI}(33), \delta \mathrm{CCl}(23)$ \\
\hline 207 & 199 & 0.55 & 1.20 & - & - & $\gamma \mathrm{CI}(16), \gamma \mathrm{CN}(14), \tau \mathrm{Ph}(13), \tau \mathrm{CO}(12)$ \\
\hline 204 & 196 & 0.49 & 1.98 & - & - & $\delta \mathrm{CI}(41), \delta \mathrm{C}_{19} \mathrm{C}_{22}(15)$ \\
\hline 179 & 172 & 0.04 & 1.88 & - & 168 & $\tau \operatorname{Pz}(69), \gamma \mathrm{CCl}(16)$ \\
\hline 164 & 157 & 0.03 & 0.00 & - & - & $\tau \mathrm{CH}_{3}(86)$ \\
\hline 147 & 142 & 1.83 & 3.94 & - & - & $\gamma \mathrm{CI}(24), \gamma \mathrm{C}_{5} \mathrm{C}_{9}(19), \tau \mathrm{Ph}(13)$ \\
\hline 132 & 127 & 1.47 & 1.80 & - & - & $\tau \mathrm{Ph}(48), \tau \mathrm{CN}(14)$ \\
\hline 90 & 87 & 1.39 & 3.03 & - & - & $\delta \mathrm{C}_{5} \mathrm{C}_{9}(28), \tau \mathrm{CI}(27), \tau \mathrm{CN}(14)$ \\
\hline 74 & 72 & 2.89 & 1.76 & - & - & $\tau \mathrm{C}_{5} \mathrm{C}_{9}(50), \tau \mathrm{CN}(27), \tau \mathrm{Ph}(11)$ \\
\hline 51 & 49 & 0.15 & 0.03 & - & - & $\tau \mathrm{CO}(40), \tau \mathrm{C}_{5} \mathrm{C}_{9}(15), \tau \mathrm{CN}(14)$ \\
\hline 36 & 35 & 0.64 & 0.01 & - & - & $\tau \mathrm{CO}(37), \tau \mathrm{CN}(27)$ \\
\hline 19 & 18 & 0.00 & 0.11 & - & - & $\tau \mathrm{CN}(63), \tau \mathrm{CO}(16)$ \\
\hline
\end{tabular}

${ }^{a} \nu$-stretching; $\delta$-in-plane deformation; $\gamma$-out-of-plane deformation; $\tau$-torsion;

$\mathrm{Ph}-\mathrm{C}_{12}-\mathrm{C}_{13}-\mathrm{C}_{15}-\mathrm{C}_{19}-\mathrm{C}_{17}-\mathrm{C}_{14} ; \mathrm{Pz}_{2}-\mathrm{C}_{1}-\mathrm{C}_{2}-\mathrm{N}_{3}-\mathrm{C}_{4}-\mathrm{C}_{5}-\mathrm{N}_{6}$.

${ }^{\mathrm{b}}$ Unscaled wavenumber.

${ }^{\mathrm{c}}$ Scaled wavenumber. 
Table 3

Second-order perturbation theory analysis of Fock matrix in NBO basis corresponding to the intramolecular bonds of the title compound.

\begin{tabular}{|c|c|c|c|c|c|c|c|c|}
\hline Donor(i) & type & ED/e & Acceptor(j) & Type & $\mathrm{ED} / \mathrm{e}$ & $\mathrm{E}(2)^{\mathrm{a}}$ & $E(j)-E(i)^{b}$ & $F(i j)^{c}$ \\
\hline $\mathrm{C}_{1}-\mathrm{N}_{6}$ & $\sigma$ & 1.98582 & $\mathrm{C}_{1}-\mathrm{C}_{2}$ & $\sigma^{*}$ & 0.05017 & 0.89 & 1.36 & 0.031 \\
\hline- & $\pi$ & $1.73005)$ & $\mathrm{C}_{2}-\mathrm{N}_{3}$ & $\pi^{*}$ & 0.32058 & 18.49 & 0.31 & 0.069 \\
\hline- & $\pi$ & - & $\mathrm{C}_{4}-\mathrm{C}_{5}$ & $\pi^{*}$ & 0.04365 & 20.70 & 0.33 & 0.075 \\
\hline $\mathrm{C}_{2}-\mathrm{N}_{3}$ & $\pi$ & 1.70809 & $\mathrm{C}_{1}-\mathrm{N}_{6}$ & $\pi^{*}$ & 0.38561 & 20.02 & 0.29 & 0.069 \\
\hline- & $\pi$ & - & $\mathrm{C}_{4}-\mathrm{C}_{5}$ & $\pi^{*}$ & 0.29757 & 22.45 & 0.32 & 0.075 \\
\hline $\mathrm{C}_{4}-\mathrm{C}_{5}$ & $\sigma$ & 1.98640 & $\mathrm{C}_{1}-\mathrm{N}_{6}$ & $\sigma^{*}$ & 0.03033 & 0.61 & 1.21 & 0.024 \\
\hline- & $\pi$ & 1.62140 & $\mathrm{C}_{1}-\mathrm{N}_{6}$ & $\pi^{*}$ & 0.38561 & 20.47 & 0.26 & 0.065 \\
\hline- & $\pi$ & - & $\mathrm{C}_{2}-\mathrm{N}_{3}$ & $\pi^{*}$ & 0.32058 & 19.14 & 0.27 & 0.065 \\
\hline- & $\pi$ & - & $\mathrm{C}_{9}-\mathrm{O}_{10}$ & $\pi^{*}$ & 0.28710 & 10.70 & 0.31 & 0.053 \\
\hline $\mathrm{C}_{12}-\mathrm{C}_{13}$ & $\sigma$ & 1.97164 & $\mathrm{~N}_{11}-\mathrm{C}_{12}$ & $\sigma^{*}$ & 0.03414 & 0.87 & 1.06 & 0.027 \\
\hline- & $\pi$ & 1.63542 & $\mathrm{C}_{14}-\mathrm{C}_{17}$ & $\pi^{*}$ & 0.39086 & 22.68 & 0.27 & 0.070 \\
\hline- & $\pi$ & - & $\mathrm{C}_{15}-\mathrm{C}_{19}$ & $\pi^{*}$ & 0.34201 & 20.85 & 0.29 & 0.070 \\
\hline $\mathrm{C}_{14}-\mathrm{C}_{17}$ & $\sigma$ & 1.97706 & $\mathrm{~N}_{11}-\mathrm{C}_{12}$ & $\sigma^{*}$ & 0.03414 & 4.21 & 1.08 & 0.060 \\
\hline- & $\pi$ & 1.72017 & $\mathrm{C}_{12}-\mathrm{C}_{13}$ & $\pi^{*}$ & 0.38599 & 18.51 & 0.30 & 0.068 \\
\hline- & $\pi$ & - & $\mathrm{C}_{15}-\mathrm{C}_{19}$ & $\pi^{*}$ & 0.34201 & 19.17 & 0.31 & 0.070 \\
\hline $\mathrm{C}_{15}-\mathrm{C}_{19}$ & $\pi$ & 1.63333 & $\mathrm{C}_{12}-\mathrm{C}_{13}$ & $\pi^{*}$ & 0.38599 & 22.77 & 0.27 & 0.070 \\
\hline- & $\pi$ & - & $\mathrm{C}_{14}-\mathrm{C}_{17}$ & $\pi^{*}$ & 0.39086 & 23.23 & 0.26 & 0.070 \\
\hline $\mathrm{LPN}_{3}$ & $\sigma$ & 1.92158 & $\mathrm{C}_{1}-\mathrm{C}_{2}$ & $\sigma^{*}$ & 0.05017 & 11.01 & 0.82 & 0.085 \\
\hline $\mathrm{LPN}_{3}$ & $\sigma$ & - & $\mathrm{C}_{4}-\mathrm{C}_{5}$ & $\sigma^{*}$ & 0.04365 & 10.63 & 0.84 & 0.085 \\
\hline $\mathrm{LPN}_{6}$ & $\sigma$ & 1.89228 & $\mathrm{C}_{1}-\mathrm{C}_{2}$ & $\sigma^{*}$ & 0.05017 & 11.12 & 0.81 & 0.086 \\
\hline $\mathrm{LPN}_{6}$ & $\sigma$ & - & $\mathrm{C}_{4}-\mathrm{C}_{5}$ & $\sigma^{*}$ & 0.04365 & 10.21 & 0.83 & 0.084 \\
\hline $\mathrm{LPO}_{10}$ & $\pi$ & - & $\mathrm{C}_{5}-\mathrm{C}_{9}$ & $\sigma^{*}$ & 0.07420 & 18.84 & 0.62 & 0.098 \\
\hline $\mathrm{LPO}_{10}$ & $\pi$ & - & $\mathrm{C}_{9}-\mathrm{N}_{11}$ & $\sigma^{*}$ & 0.07354 & 22.46 & 0.65 & 0.109 \\
\hline $\mathrm{LPN}_{11}$ & $\sigma$ & - & $\mathrm{C}_{9}-\mathrm{O}_{10}$ & $\pi^{*}$ & 0.28710 & 50.74 & 0.29 & 0.109 \\
\hline $\mathrm{LPN}_{11}$ & $\sigma$ & - & $\mathrm{C}_{12}-\mathrm{C}_{13}$ & $\pi^{*}$ & 0.38599 & 31.00 & 0.31 & 0.088 \\
\hline $\mathrm{LPCl}_{27}$ & $\mathrm{n}$ & 1.91841 & $\mathrm{C}_{1}-\mathrm{N}_{6}$ & $\pi^{*}$ & 0.38561 & 14.26 & 0.27 & 0.060 \\
\hline
\end{tabular}

Table 4

NBO results showing the formation of Lewis and non-Lewis orbitals of title compound.

\begin{tabular}{|l|l|l|l|l|l|l|}
\hline Bond(A-B) & ED/ea & EDA\% & EDB\% & NBO & $\mathrm{s} \%$ & $\mathrm{p} \%$ \\
\hline$\sigma \mathrm{C}_{1}-\mathrm{C}_{2}$ & 1.99140 & 50.76 & 49.24 & $0.7125\left(\mathrm{sp}^{1.40}\right) \mathrm{C}$ & 41.67 & 58.33 \\
- & -0.78221 & - & - & $+0.7017\left(\mathrm{sp}^{1.77}\right) \mathrm{C}$ & 36.14 & 63.86 \\
\hline$\sigma \mathrm{C}_{1}-\mathrm{N}_{6}$ & 1.98582 & 39.57 & 60.43 & $0.6290\left(\mathrm{sp}^{1.87}\right) \mathrm{C}$ & 34.86 & 65.14 \\
- & -0.98582 & - & - & $+0.7774\left(\mathrm{sp}^{1.75}\right) \mathrm{N}$ & 36.41 & 63.59 \\
\hline$\pi \mathrm{C}_{1}-\mathrm{N}_{6}$ & 1.73005 & 45.46 & 54.54 & $0.6742\left(\mathrm{sp}^{1.00}\right) \mathrm{C}$ & 0.00 & 100.00 \\
- & -0.36803 & - & - & $+0.7385\left(\mathrm{sp}^{1.00}\right) \mathrm{N}$ & 0.00 & 100.00 \\
\hline$\sigma \mathrm{C}_{1}-\mathrm{Cl}_{27}$ & 1.98115 & 43.96 & 56.04 & $0.6630\left(\mathrm{sp}^{3.28}\right) \mathrm{C}$ & 23.38 & 76.62 \\
- & -0.70944 & - & - & $+0.7486\left(\mathrm{sp}^{5.94}\right) \mathrm{C}$ & 14.42 & 85.58 \\
\hline$\sigma \mathrm{C}_{2}-\mathrm{N}_{3}$ & 1.98229 & 40.06 & 59.94 & $0.6329\left(\mathrm{sp}^{2.18}\right) \mathrm{C}$ & 31.47 & 68.53 \\
- & --0.34997 & & - & $+0.7742\left(\mathrm{sp}^{1.90}\right) \mathrm{N}$ & 34.49 & 65.51 \\
\hline$\pi \mathrm{C}_{2}-\mathrm{N}_{3}$ & 1.70809 & 42.91 & 57.09 & $0.6551\left(\mathrm{sp}^{1.00}\right) \mathrm{C}$ & 0.00 & 100.00 \\
\hline
\end{tabular}




\begin{tabular}{|c|c|c|c|c|c|c|}
\hline - & -0.87490 & - & - & $+0.7556\left(\mathrm{sp}^{1.00}\right) \mathrm{N}$ & 0.00 & 100.00 \\
\hline$\sigma \mathrm{N}_{3}-\mathrm{C}_{4}$ & $\begin{array}{l}1.98489 \\
-0.86687\end{array}$ & $\begin{array}{l}59.97 \\
-\end{array}$ & $\begin{array}{l}40.03 \\
-\end{array}$ & $\begin{array}{l}0.7744\left(\mathrm{sp}^{1.90}\right) \mathrm{N} \\
+0.6327(\mathrm{sp} 2.24) \mathrm{C}\end{array}$ & $\begin{array}{l}34.45 \\
30.82\end{array}$ & $\begin{array}{l}65.55 \\
69.18\end{array}$ \\
\hline $\begin{array}{l}\sigma \mathrm{C}_{4}-\mathrm{C}_{5} \\
-\end{array}$ & $\begin{array}{l}1.98640 \\
-0.76925\end{array}$ & $\begin{array}{l}49.27 \\
-\end{array}$ & $\begin{array}{l}50.73 \\
-\end{array}$ & $\begin{array}{l}0.7019\left(\mathrm{sp}^{1.69}\right) \mathrm{C} \\
+0.7122\left(\mathrm{sp}^{1.70}\right) \mathrm{C}\end{array}$ & $\begin{array}{l}37.19 \\
37.09\end{array}$ & $\begin{array}{l}62.81 \\
62.91\end{array}$ \\
\hline$\pi \mathrm{C}_{4}-\mathrm{C}_{5}$ & $\begin{array}{l}1.62140 \\
-0.31939\end{array}$ & $\begin{array}{l}49.06 \\
-\end{array}$ & $\begin{array}{l}50.94 \\
-\end{array}$ & $\begin{array}{l}0.7004\left(\mathrm{sp}^{1.00}\right) \mathrm{C} \\
+0.7137\left(\mathrm{sp}^{99.99}\right) \mathrm{C}\end{array}$ & $\begin{array}{l}0.01 \\
0.01\end{array}$ & $\begin{array}{l}99.99 \\
99.99\end{array}$ \\
\hline$\sigma \mathrm{C}_{5}-\mathrm{N}_{6}$ & $\begin{array}{l}1.97150 \\
-0.87076\end{array}$ & $\begin{array}{l}39.88 \\
-\end{array}$ & $\begin{array}{l}60.12 \\
-\end{array}$ & $\begin{array}{l}0.6315\left(\mathrm{sp}^{2.28}\right) \mathrm{C} \\
+0.7754\left(\mathrm{sp}^{1.86}\right) \mathrm{N}\end{array}$ & $\begin{array}{l}30.46 \\
34.96\end{array}$ & $\begin{array}{l}69.54 \\
65.04\end{array}$ \\
\hline $\begin{array}{l}\sigma \mathrm{C}_{5}-\mathrm{C}_{9} \\
-\end{array}$ & $\begin{array}{l}1.96638 \\
-0.69127\end{array}$ & $\begin{array}{l}52.10 \\
-\end{array}$ & $\begin{array}{l}47.90 \\
-\end{array}$ & $\begin{array}{l}0.7218\left(\mathrm{sp}^{2.08}\right) \mathrm{C} \\
+0.6921\left(\mathrm{sp}^{1.91}\right) \mathrm{C}\end{array}$ & $\begin{array}{l}32.43 \\
34.35\end{array}$ & $\begin{array}{l}67.57 \\
65.65\end{array}$ \\
\hline $\begin{array}{l}\sigma \mathrm{C}_{9}-\mathrm{O}_{10} \\
-\end{array}$ & $\begin{array}{l}1.98952 \\
-1.00167 \\
\end{array}$ & $\begin{array}{l}34.60 \\
- \\
\end{array}$ & $\begin{array}{l}65.40 \\
-\quad \\
\end{array}$ & $\begin{array}{l}0.5883\left(\mathrm{sp}^{2.13}\right) \mathrm{C} \\
+0.8087\left(\mathrm{sp}^{1.97}\right) \mathrm{O}\end{array}$ & $\begin{array}{l}31.90 \\
33.67\end{array}$ & $\begin{array}{l}68.10 \\
66.33 \\
\end{array}$ \\
\hline $\begin{array}{l}\pi \mathrm{C}_{9}-\mathrm{O}_{10} \\
-\end{array}$ & $\begin{array}{l}1.97656 \\
-0.42140\end{array}$ & $\begin{array}{l}32.17 \\
-\end{array}$ & $\begin{array}{l}67.83 \\
-\end{array}$ & $\begin{array}{l}0.5672\left(\mathrm{sp}^{55.54}\right) \mathrm{C} \\
+0.8236\left(\mathrm{sp}^{54.69}\right) \mathrm{O}\end{array}$ & $\begin{array}{l}1.77 \\
1.80\end{array}$ & $\begin{array}{l}98.23 \\
98.20\end{array}$ \\
\hline $\begin{array}{l}\sigma \mathrm{C}_{9}-\mathrm{N}_{11} \\
-\end{array}$ & $\begin{array}{l}1.98598 \\
-0.85300\end{array}$ & $\begin{array}{l}36.36 \\
-\end{array}$ & $\begin{array}{l}63.64 \\
-\end{array}$ & $\begin{array}{l}0.6030\left(\mathrm{sp}^{2.12}\right) \mathrm{C} \\
+0.7978\left(\mathrm{sp}^{1.78}\right) \mathrm{N}\end{array}$ & $\begin{array}{l}32.03 \\
35.92\end{array}$ & $\begin{array}{l}67.97 \\
64.08\end{array}$ \\
\hline$\sigma \mathrm{N}_{11-}-\mathrm{C}_{12}$ & $\begin{array}{l}1.98280 \\
-0.81409\end{array}$ & $\begin{array}{l}63.01 \\
-\end{array}$ & $\begin{array}{l}36.99 \\
-\end{array}$ & $\begin{array}{l}0.7938\left(\mathrm{sp}^{1.69}\right) \mathrm{N} \\
+0.6082\left(\mathrm{sp}^{2.68}\right) \mathrm{C}\end{array}$ & $\begin{array}{l}37.19 \\
27.16\end{array}$ & $\begin{array}{l}62.81 \\
72.84\end{array}$ \\
\hline$\sigma \mathrm{C}_{12}-\mathrm{C}_{13}$ & $\begin{array}{l}1.97164 \\
-0.70877\end{array}$ & $\begin{array}{l}51.28 \\
-\end{array}$ & $\begin{array}{l}48.72 \\
-\end{array}$ & $\begin{array}{l}0.7161(\mathrm{sp} 1.68) \mathrm{C} \\
+0.6980\left(\mathrm{sp}^{1.96}\right) \mathrm{C}\end{array}$ & $\begin{array}{l}37.34 \\
33.79\end{array}$ & $\begin{array}{l}62.66 \\
66.21\end{array}$ \\
\hline$\pi \mathrm{C}_{12}-\mathrm{C}_{13}$ & $\begin{array}{l}1.63542 \\
-0.26987 \\
\end{array}$ & $\begin{array}{l}51.24 \\
- \\
\end{array}$ & $\begin{array}{l}48.76 \\
-\quad \\
\end{array}$ & $\begin{array}{l}0.758\left(\mathrm{sp}^{1.00}\right) \mathrm{C} \\
+0.6983\left(\mathrm{sp}^{1.00}\right) \mathrm{C}\end{array}$ & $\begin{array}{l}0.00 \\
0.00\end{array}$ & $\begin{array}{l}100.00 \\
100.00\end{array}$ \\
\hline$\sigma \mathrm{C}_{12}-\mathrm{C}_{14}$ & $\begin{array}{l}1.96297 \\
-0.71281\end{array}$ & $\begin{array}{l}50.28 \\
-\end{array}$ & $\begin{array}{l}49.72 \\
-\end{array}$ & $\begin{array}{l}0.7091\left(\mathrm{sp}^{1.82}\right) \mathrm{C} \\
+0.7051\left(\mathrm{sp}^{1.83}\right) \mathrm{C}\end{array}$ & $\begin{array}{l}35.41 \\
35.35\end{array}$ & $\begin{array}{l}64.59 \\
64.65\end{array}$ \\
\hline$\sigma \mathrm{C}_{13}-\mathrm{C}_{15}$ & $\begin{array}{l}1.97541 \\
-0.69942\end{array}$ & $\begin{array}{l}50.06 \\
-\end{array}$ & $\begin{array}{l}49.94 \\
-\quad\end{array}$ & $\begin{array}{l}0.7075\left(\mathrm{sp}^{1.80}\right) \mathrm{C} \\
+0.7067\left(\mathrm{sp}^{1.80}\right) \mathrm{C}\end{array}$ & $\begin{array}{l}35.73 \\
35.67\end{array}$ & $\begin{array}{l}64.27 \\
64.33\end{array}$ \\
\hline$\sigma \mathrm{C}_{14-} \mathrm{C}_{17}$ & $\begin{array}{l}1.97706 \\
-0.73587\end{array}$ & $\begin{array}{l}50.02 \\
-\end{array}$ & $\begin{array}{l}49.98 \\
-\end{array}$ & $\begin{array}{l}0.7072\left(\mathrm{sp}^{1.74}\right) \mathrm{C} \\
+0.7070\left(\mathrm{sp}^{1.53}\right) \mathrm{C}\end{array}$ & $\begin{array}{l}36.45 \\
39.45\end{array}$ & $\begin{array}{l}63.55 \\
60.55\end{array}$ \\
\hline$\pi \mathrm{C}_{14}-\mathrm{C}_{17}$ & $\begin{array}{l}1.72017 \\
-0.28552\end{array}$ & $\begin{array}{l}48.11 \\
-\end{array}$ & $\begin{array}{l}51.89 \\
-\end{array}$ & $\begin{array}{l}0.6936\left(\mathrm{sp}^{1.00}\right) \mathrm{C} \\
+0.7203\left(\mathrm{sp}^{1.00}\right) \mathrm{C}\end{array}$ & $\begin{array}{l}0.00 \\
0.00\end{array}$ & $\begin{array}{l}100.00 \\
100.00\end{array}$ \\
\hline$\sigma \mathrm{C}_{15}-\mathrm{C}_{19}$ & $\begin{array}{l}1.96170 \\
-0.69504\end{array}$ & $\begin{array}{l}49.31 \\
-\end{array}$ & $\begin{array}{l}50.69 \\
-\end{array}$ & $\begin{array}{l}0.7022\left(\mathrm{sp}^{1.77}\right) \mathrm{C} \\
+0.7120\left(\mathrm{sp}^{1.93}\right) \mathrm{C}\end{array}$ & $\begin{array}{l}36.11 \\
34.07\end{array}$ & $\begin{array}{l}63.89 \\
65.93\end{array}$ \\
\hline $\begin{array}{l}\pi \mathrm{C}_{15}-\mathrm{C}_{19} \\
-\end{array}$ & $\begin{array}{l}1.63333 \\
-0.25852 \\
\end{array}$ & $\begin{array}{l}49.99 \\
-\quad \\
\end{array}$ & $\begin{array}{l}50.01 \\
- \\
\end{array}$ & $\begin{array}{l}0.7070\left(\mathrm{sp}^{1.00}\right) \mathrm{C} \\
+0.7072\left(\mathrm{sp}^{1.00}\right) \mathrm{C}\end{array}$ & $\begin{array}{l}0.00 \\
0.00\end{array}$ & $\begin{array}{l}100.00 \\
100.00\end{array}$ \\
\hline$\sigma \mathrm{C}_{17}-\mathrm{C}_{19}$ & $\begin{array}{l}1.97709 \\
-0.72842\end{array}$ & $\begin{array}{l}50.40 \\
-\end{array}$ & $\begin{array}{l}49.60 \\
-\quad\end{array}$ & $\begin{array}{l}0.7100\left(\mathrm{sp}^{1.43}\right) \mathrm{C} \\
+0.7042\left(\mathrm{sp}^{1.94}\right) \mathrm{C}\end{array}$ & $\begin{array}{l}41.11 \\
34.01\end{array}$ & $\begin{array}{l}58.89 \\
65.99\end{array}$ \\
\hline$\sigma \mathrm{C}_{17}-\mathrm{I}_{26}$ & $\begin{array}{l}1.97175 \\
-0.49972\end{array}$ & $\begin{array}{l}53.77 \\
-\end{array}$ & $\begin{array}{l}46.23 \\
-\end{array}$ & $\begin{array}{l}0.7333\left(\mathrm{sp}^{4.06}\right) \mathrm{C} \\
+0.6799\left(\mathrm{sp}^{8.65}\right) \mathrm{C}\end{array}$ & $\begin{array}{l}19.78 \\
10.37\end{array}$ & $\begin{array}{l}80.22 \\
89.63\end{array}$ \\
\hline $\begin{array}{l}\sigma \mathrm{C}_{19}-\mathrm{C}_{22} \\
- \\
\end{array}$ & $\begin{array}{l}1.97831 \\
-0.63165 \\
\end{array}$ & $\begin{array}{l}50.95 \\
- \\
\end{array}$ & $\begin{array}{l}49.09 \\
-\quad \\
\end{array}$ & $\begin{array}{l}0.7138\left(\mathrm{sp}^{2.14}\right) \mathrm{C} \\
+0.7004\left(\mathrm{sp}^{2.35}\right) \mathrm{C}\end{array}$ & $\begin{array}{l}31.89 \\
29.84 \\
\end{array}$ & $\begin{array}{l}68.11 \\
70.16 \\
\end{array}$ \\
\hline$n 1 N_{3}$ & $\begin{array}{l}1.92158 \\
-0.38057\end{array}$ & - & - & $\begin{array}{l}\text { Sp2.21 } \\
-\end{array}$ & $\begin{array}{l}31.11 \\
-\end{array}$ & $\begin{array}{l}68.89 \\
-\end{array}$ \\
\hline $\begin{array}{ll}n \\
n\end{array}$ & $\begin{array}{l}1.89228 \\
-0.37174 \\
\end{array}$ & - & - & $\begin{array}{l}\text { Sp2.49 } \\
-\end{array}$ & $\begin{array}{l}28.68 \\
- \\
\end{array}$ & $\begin{array}{l}71.32 \\
-\quad \\
\end{array}$ \\
\hline $\begin{array}{l}\mathrm{n} 1 \mathrm{O}_{10} \\
- \\
\end{array}$ & $\begin{array}{l}1.97545 \\
-0.70487 \\
\end{array}$ & - & - & $\begin{array}{l}\text { Sp0.55 } \\
-\end{array}$ & $\begin{array}{l}64.52 \\
-\quad \\
\end{array}$ & $\begin{array}{l}35.48 \\
- \\
\end{array}$ \\
\hline${\mathrm{n} 2 \mathrm{O}_{10}}$ & $\begin{array}{l}1.87439 \\
-0.27662\end{array}$ & - & - & $\begin{array}{l}\text { Sp99.99 } \\
-\end{array}$ & $\begin{array}{l}0.06 \\
-\end{array}$ & $\begin{array}{l}99.94 \\
-\end{array}$ \\
\hline
\end{tabular}




\begin{tabular}{|l|l|l|l|l|l|l|}
\hline $\mathrm{n} 1 \mathrm{~N}_{11}$ & 1.65763 & - & - & $\mathrm{Sp99.99}$ & 0.07 & 99.93 \\
- & -0.29824 & & - & - & - \\
\hline $1 \mathrm{I}_{26}$ & 1.99300 & - & - & $\mathrm{Sp0} .12$ & 89.54 & 10.46 \\
- & -0.61887 & & - & - & - \\
\hline $\mathrm{n} 2 \mathrm{I}_{26}$ & 1.97743 & - & - & $\mathrm{Sp99.99}$ & 0.14 & 99.86 \\
- & -0.27418 & & - & - & - \\
\hline $\mathrm{n} 3 \mathrm{I}_{26}$ & 1.95066 & - & - & $\mathrm{Sp0.17}$ & 0.00 & 100.00 \\
- & -0.27235 & & - & - & - \\
\hline $\mathrm{n} 1 \mathrm{Cl}_{27}$ & 1.99197 & - & - & $\mathrm{Sp0.17}$ & 85.15 & 14.85 \\
- & -0.94724 & & - & - & - \\
\hline $\mathrm{n} 2 \mathrm{Cl}_{27}$ & 1.97091 & - & - & $\mathrm{Sp} 99.99$ & 0.44 & 99.56 \\
- & -0.33659 & & & - & - & - \\
\hline $\mathrm{n} 3 \mathrm{Cl}_{27}$ & 1.91841 & - & - & $\mathrm{Sp} 1.00$ & 0.00 & 100.00 \\
- & -0.33348 & & - & - & - \\
\hline
\end{tabular}

Table 5

Polarizability values of CIMPPC with halogen substitutions

\begin{tabular}{|l|l|l|l|l|}
\hline & $\mu$ debye & $\alpha \times 10^{-23} \mathrm{esu}$ & $\beta \times 10^{-30} \mathrm{esu}$ & $\gamma \times 10^{-37} \mathrm{esu}$ \\
\hline $26 \mathrm{I}$ & 3.5147 & 2.782 & 24.973 & -21.240 \\
\hline $26 \mathrm{Br}$ & 3.3623 & 2.756 & 25.460 & -19.876 \\
\hline $26 \mathrm{Cl}$ & 3.5352 & 2.671 & 24.853 & -18.287 \\
\hline $26 \mathrm{~F}$ & 3.0499 & 2.500 & 26.287 & -15.968 \\
\hline $16 \mathrm{I}$ & 1.6246 & 2.790 & 32.504 & -17.348 \\
\hline $16 \mathrm{Br}$ & 1.1896 & 2.727 & 21.866 & -16.345 \\
\hline $16 \mathrm{Cl}$ & 1.1041 & 2.650 & 21.835 & -15.686 \\
\hline $16 \mathrm{~F}$ & 1.3843 & 2.503 & 24.355 & -14.868 \\
\hline $18 \mathrm{I}$ & 1.7722 & 1.795 & 5.402 & -17.668 \\
\hline $18 \mathrm{Br}$ & 2.9675 & 2.605 & 36.782 & -16.441 \\
\hline $18 \mathrm{Cl}$ & 3.1251 & 2.527 & 3.269 & -15.783 \\
\hline $18 \mathrm{~F}$ & 2.8580 & 2.409 & 8.735 & -14.933 \\
\hline $20 \mathrm{I}$ & 0.7531 & 2.845 & 38.874 & -21.595 \\
\hline $20 \mathrm{Br}$ & 0.8064 & 2.756 & 26.477 & -19.683 \\
\hline $20 \mathrm{Cl}$ & 0.7935 & 2.671 & 25.702 & -18.086 \\
\hline $20 \mathrm{~F}$ & 0.9418 & 2.500 & 26.808 & -15.878 \\
\hline
\end{tabular}

Table 6

HOMO, LUMO and Chemical descriptors of CIMPPC with halogen substitutions

\begin{tabular}{|l|l|l|l|l|l|l|l|l|}
\hline & HOMO & LUMO & $\mathrm{I}=-\mathrm{E}_{\text {HOMO }}$ & $\mathrm{A}=-\mathrm{E}_{\text {LUMO }}$ & Gap & $\eta=(\mathrm{I}-\mathrm{A}) / 2$ & $\mu=(\mathrm{I}+\mathrm{A}) / 2$ & $\omega=\mu^{2} / 2 \eta$ \\
\hline $26 \mathrm{I}$ & -0.21808 & -0.18744 & 5.934 & 5.100 & 0.834 & 0.417 & -5.517 & 36.496 \\
\hline $26 \mathrm{Br}$ & -0.29757 & -0.18747 & 8.097 & 5.101 & 2.996 & 1.498 & -6.599 & 14.535 \\
\hline $26 \mathrm{Cl}$ & -0.29652 & -0.18722 & 8.069 & 5.094 & 2.975 & 1.488 & -6.582 & 14.557 \\
\hline $26 \mathrm{~F}$ & -0.29755 & -0.18727 & 8.097 & 5.096 & 3.001 & 1.501 & -6.597 & 14.497 \\
\hline $16 \mathrm{I}$ & -0.22020 & -0.18879 & 5.992 & 5.137 & 0.885 & 0.428 & -5.565 & 36.179 \\
\hline
\end{tabular}




\begin{tabular}{|l|l|l|l|l|l|l|l|l|}
\hline $16 \mathrm{Br}$ & -0.29750 & -0.18761 & 8.095 & 5.105 & 2.990 & 1.495 & -6.600 & 14.569 \\
\hline $16 \mathrm{Cl}$ & -0.28821 & -0.18699 & 7.842 & 5.088 & 2.754 & 1.377 & -6.465 & 15.177 \\
\hline $16 \mathrm{~F}$ & -0.29707 & -0.18725 & 8.084 & 5.095 & 2.989 & 1.495 & -6.590 & 14.524 \\
\hline $18 \mathrm{I}$ & -0.21454 & -0.18622 & 5.838 & 5.067 & 0.771 & 0.386 & -5.453 & 38.517 \\
\hline $18 \mathrm{Br}$ & -0.29766 & -0.18473 & 8.100 & 5.027 & 3.073 & 1.537 & -6.564 & 14.016 \\
\hline $18 \mathrm{Cl}$ & -0.29480 & -0.18431 & 8.021 & 5.015 & 3.006 & 1.503 & -6.518 & 14.133 \\
\hline $18 \mathrm{~F}$ & -0.29757 & -0.18523 & 8.097 & 5.040 & 3.057 & 1.529 & -6.569 & 14.111 \\
\hline $20 \mathrm{I}$ & -0.21820 & -0.18876 & 5.937 & 5.136 & 0.801 & 0.401 & -5.537 & 38.227 \\
\hline $20 \mathrm{Br}$ & -0.29756 & -0.18742 & 8.097 & 5.100 & 2.997 & 1.499 & -6.599 & 14.525 \\
\hline $20 \mathrm{Cl}$ & -0.29713 & -0.18705 & 8.085 & 5.090 & 2.995 & 1.498 & -6.588 & 14.487 \\
\hline $20 \mathrm{~F}$ & -0.29754 & -0.18709 & 8.096 & 5.091 & 3.005 & 1.503 & -6.594 & 14.465 \\
\hline
\end{tabular}

Table 7

Values of solubility parameters $\delta\left[\mathrm{MPa}^{1 / 2}\right]$ for studied molecules and the excipient

\begin{tabular}{|l|l|}
\hline Molecules & $\delta\left[\mathrm{MPa}^{1 / 2}\right]$ \\
\hline CIMPPC & 23.426 \\
\hline PVP & 18.515 \\
\hline Maltose & 28.564 \\
\hline Sorbitol & 32.425 \\
\hline
\end{tabular}

\section{Table 8}

PASS prediction for the activity spectrum of CIMPPC compound. Pa represents probability to be active and Pi represents probability to be inactive.
$\mathrm{Pa} \quad \mathrm{Pi} \quad$ Activity
$0.708 \quad 0.003$ Vanilloid 1 agonist
0.6750 .078 Ubiquinol-cytochrome-c reductase inhibitor
$0.477 \quad 0.003$ Vanilloid agonist
0.4310 .056 Platelet derived growth factor receptor kinase inhibitor
$0.370 \quad 0.007$ Lymphocytopoiesis inhibitor
$0.408 \quad 0.083$ Erythropoiesis stimulant
0.4660 .142 Nicotinic alpha6beta3beta4alpha5 receptor antagonist
$\begin{array}{lll}0.350 & 0.027 & \text { Imidazoline I1 receptor agonist }\end{array}$
$0.363 \quad 0.050 \mathrm{CF}$ transmembrane conductance regulator agonist
0.3350 .038 Antineoplastic (pancreatic cancer)
0.3240 .030 Thyroxine 5-deiodinase inhibitor
0.3740 .085 Peptide agonist
0.3640 .076 Centromere associated protein inhibitor
$\begin{array}{lll}0.316 & 0.037 & \text { Thiamine pyridinylase inhibitor }\end{array}$ 
$0.352 \quad 0.074$ Autoimmune disorders treatment

0.3620 .0935 Hydroxytryptamine release inhibitor

0.3020 .037 Antihelmintic

0.2840 .022 Pancreatic disorders treatment

0.3520 .095 RNA-directed RNA polymerase inhibitor

0.3170 .062 Antituberculosic

0.2760 .023 Blasticidin-S deaminase inhibitor

0.2850 .038 Sodium channel blocker

$0.296 \quad 0.057$ Antiparasitic

0.2350 .003 Sodiumhydrogen exchanger 5 inhibitor

0.3620 .143 Nicotinic alpha2beta2 receptor antagonist

0.2360 .023 Aurora-C kinase inhibitor

0.2310 .018 Complement inhibitor

\section{Table 9}

The binding affinity values of different poses of the compound CIMPPC predicted by Autodock Vina.

Mode Affinity (kcal/mol) Distance from best mode $(\AA)$

RMSD 1.b. RMSD u.b.

\begin{tabular}{llll}
\hline 1 & -5.9 & 0.000 & 0.000 \\
2 & -5.7 & 1.649 & 2.135 \\
3 & -5.6 & 18.110 & 20.686 \\
4 & -5.4 & 3.679 & 6.984 \\
5 & -5.4 & 17.560 & 19.338 \\
6 & -5.3 & 17.033 & 18.815 \\
7 & -5.3 & 17.397 & 19.392 \\
8 & -5.3 & 12.883 & 15.474 \\
9 & -5.3 & 3.992 & 7.341 \\
\hline
\end{tabular}

